\title{
The Novel Cyclin-Dependent Kinase 4/6 Inhibitor Ribociclib (LEE011) Alone and in Dual-Targeting Approaches Demonstrates Antitumoral Efficacy in Neuroendocrine Tumors in vitro
}

\author{
Aristizabal Prada, Elke Tatjana ; Nölting, Svenja ; Spoettl, Gerald ; Maurer, Julian ; Auernhammer, \\ Christoph Josef
}

\begin{abstract}
BACKGROUND/AIM Cyclin-dependent kinases (CDKs) are crucial for cell cycle regulation, and alterations in the cell cycle are often observed in human cancer. CDK4/6 in particular orchestrates G1 phase progression and the G1/S transition. Here, we investigated the in vitro effects of the CDK4/6 inhibitor LEE011 in human neuroendocrine tumor cells. METHODS The human neuroendocrine tumor cell lines BON1, QGP1, NCI-H727 and GOT1 were treated with different concentrations of LEE011 alone and in combination with 5-fluorouracil and everolimus. RESULTS Cell viability decreased in a time- and dose-dependent manner in BON1, QGP1, and NCI-H727 cells upon LEE011 treatment, whereas GOT1 cells were treatment resistant. Treatment sensitivity towards LEE011 was associated with the high expression of cyclin D1 and Rb. LEE011 caused the dephosphorylation of Rb and a subsequent G1 phase cell cycle arrest. Combined treatment with LEE011 and 5-fluorouracil or everolimus showed a significant enhancement in the inhibition of cell viability when compared to single-substance treatments due to PI3KAkt-mTOR and Ras-Raf-MEK-ERK pathway downregulation and cooperative downregulation of cell cycle components. However, LEE011 also exhibited antagonizing effects with 5-fluorouracil, protecting NET cells from DNA-damaging chemotherapy by blocking PARP cleavage and caspase-3/7 activity. CONCLUSIONS Our data demonstrate that the CDK 4/6 inhibitor LEE011 exhibits promising antitumoral properties alone and in combination treatment approaches with 5 -fluorouracil or everolimus in human neuroendocrine tumor cell lines.
\end{abstract}

DOI: https://doi.org/10.1159/000463386

Posted at the Zurich Open Repository and Archive, University of Zurich

ZORA URL: https://doi.org/10.5167/uzh-208188

Journal Article

Published Version

Originally published at:

Aristizabal Prada, Elke Tatjana; Nölting, Svenja; Spoettl, Gerald; Maurer, Julian; Auernhammer, Christoph Josef (2018). The Novel Cyclin-Dependent Kinase 4/6 Inhibitor Ribociclib (LEE011) Alone and in Dual-Targeting Approaches Demonstrates Antitumoral Efficacy in Neuroendocrine Tumors in vitro. Neuroendocrinology, 106(1):58-73.

DOI: https://doi.org/10.1159/000463386 


\title{
The Novel Cyclin-Dependent Kinase 4/6 Inhibitor Ribociclib (LEE011) Alone and in Dual-Targeting Approaches Demonstrates Antitumoral Efficacy in Neuroendocrine Tumors in vitro
}

\author{
Elke Tatjana Aristizabal Prada ${ }^{a}$ Svenja Nölting ${ }^{a, b}$ Gerald Spoettl ${ }^{a}$ \\ Julian Maurer $^{\mathrm{a}}$ Christoph Josef Auernhammer ${ }^{\mathrm{a}, \mathrm{b}}$ \\ ${ }^{a}$ Department of Internal Medicine II, Campus Grosshadern, and ${ }^{b}$ Interdisciplinary Center of Neuroendocrine Tumors \\ of the GastroEnteroPancreatic System (GEPNET-KUM), University Hospital, Ludwig-Maximilians University of \\ Munich, Munich, Germany
}

\section{Keywords}

CDK4/6 inhibitor · Ribociclib · LEE011 - Neuroendocrine tumor · Dual targeting

\begin{abstract}
Background/Aim: Cyclin-dependent kinases (CDKs) are crucial for cell cycle regulation, and alterations in the cell cycle are often observed in human cancer. CDK4/6 in particular orchestrates $\mathrm{G} 1$ phase progression and the $\mathrm{G} 1 / \mathrm{S}$ transition. Here, we investigated the in vitro effects of the CDK4/6 inhibitor LEE011 in human neuroendocrine tumor cells. Methods: The human neuroendocrine tumor cell lines BON1, QGP1, NCl-H727 and GOT1 were treated with different concentrations of LEE011 alone and in combination with 5-fluorouracil and everolimus. Results: Cell viability decreased in a time- and dose-dependent manner in BON1, QGP1, and NClH727 cells upon LEE011 treatment, whereas GOT1 cells were treatment resistant. Treatment sensitivity towards LEE011 was associated with the high expression of cyclin D1 and Rb. LEE011 caused the dephosphorylation of $\mathrm{Rb}$ and a subsequent G1 phase cell cycle arrest. Combined treatment with
\end{abstract}

\section{KARGER}

(C) 2017 S. Karger AG, Basel

E-Mail karger@karger.com

www.karger.com/nen
LEE011 and 5-fluorouracil or everolimus showed a significant enhancement in the inhibition of cell viability when compared to single-substance treatments due to PI3K-AktmTOR and Ras-Raf-MEK-ERK pathway downregulation and cooperative downregulation of cell cycle components. However, LEE011 also exhibited antagonizing effects with 5-fluorouracil, protecting NET cells from DNA-damaging chemotherapy by blocking PARP cleavage and caspase-3/7 activity. Conclusions: Our data demonstrate that the CDK 4/6 inhibitor LEE011 exhibits promising anti-tumoral properties alone and in combination treatment approaches with 5-fluorouracil or everolimus in human neuroendocrine tumor cell lines.

(c) 2017 S. Karger AG, Basel

\section{Introduction}

Gastroenteropancreatic neuroendocrine tumors (GEP-NETs) are the second most common gastrointestinal malignancy after colorectal cancer [1]. Due to the variable cellular and tumor phenotypes of GEP-NETs, the clinical presentation is nonspecific; hence, the diag-
Christoph Joseph Auernhammer

Department of Internal Medicine II, Campus Grosshadern, University Hospital Ludwig-Maximilians University of Munich, Marchioninistrasse 15 DE-81377 Munich (Germany)

E-Mail christoph.auernhammer@med.uni-muenchen.de 
Fig. 1. Proposed and simplified mode of action of the CDK4/6 inhibitor LEE011 on the cell cycle. a Activated cyclinD-CDK4/6$\mathrm{Rb}$ axis leads to $\mathrm{G} 1 / \mathrm{S}$ cell cycle progression via the phosphorylation of $\mathrm{Rb}$ and subsequent activation of the transcription factor E2F. b Blocking the cyclinD-CDK4/6-Rb axis leads to G1 phase cell cycle arrest through either the endogenous CDK4/6 inhibitor p16 or the small molecule CDK4/6 inhibitor LEE011.
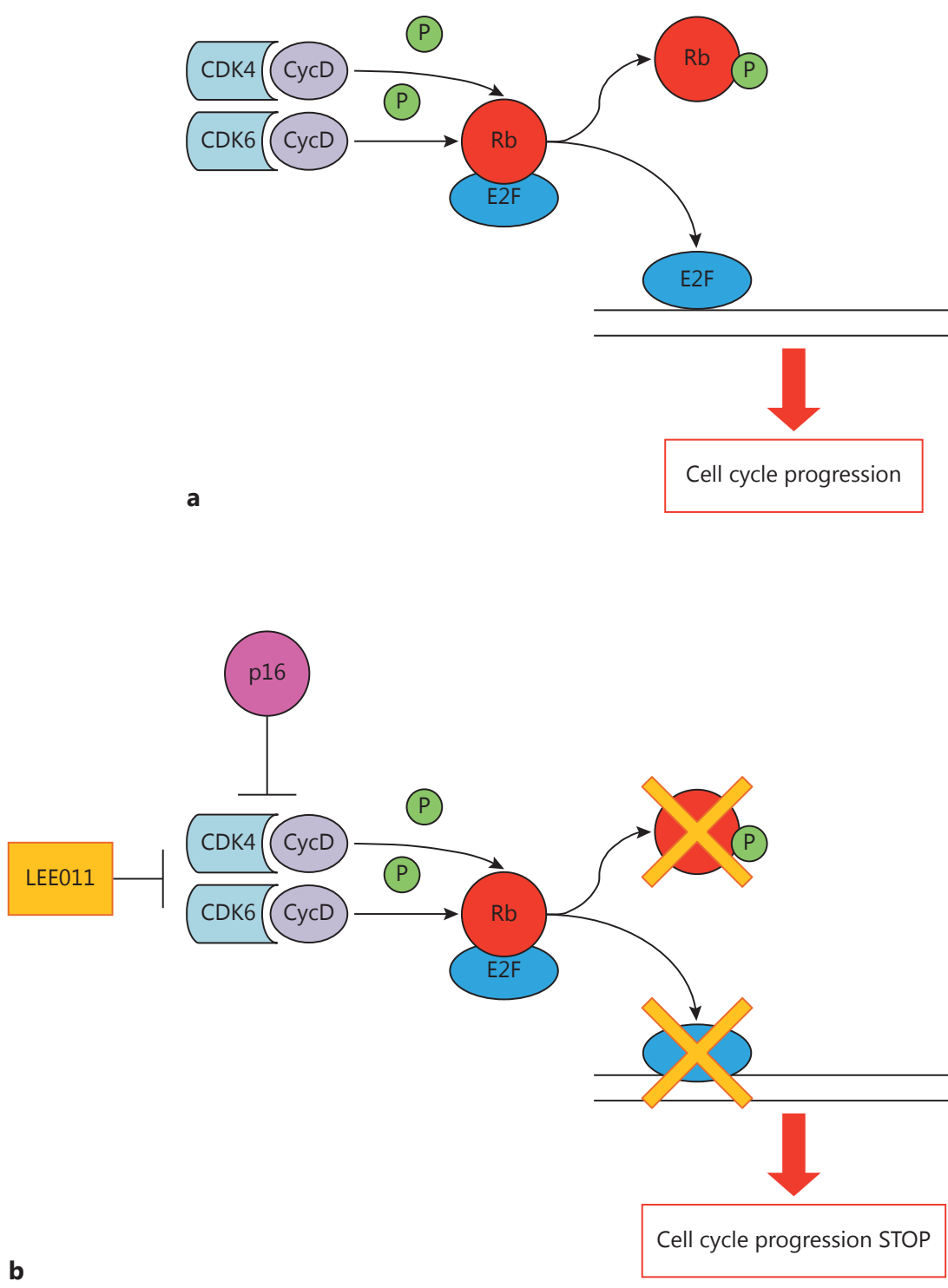

nosis is often at a late and an advanced metastatic state [1, 2]. The paucity of successful targeting agents for GEPNETs is mostly due to the complexity and the rarity of GEP-NETs, as well as the intrinsic differences in malignant potential because of their heterogeneity and the dissimilar clinical presentation $[1,3]$. Current therapeutic approaches for GEP-NETs, such as biotherapy, molecular targeted therapy, chemotherapy, and peptide receptor radionuclide therapy are limited in their effectiveness; ergo, new strategies are urgently needed [4]. The cyclin-dependent kinases (CDKs) are the main regulators of the cell cycle transition and catalyze the phosphorylation of key proteins and transcription factors, and the aberrant expression of these CDKs due to gene mutation, amplification or overexpression often leads to cancer cell formation [5]. In addition to CDKs, their associated substrates (cyclins) are expressed in a spatiotemporal-dependent manner, enabling a controlled step-by-step cell cycle progression [6]. In particular, the complexes cyclinD-CDK4 and cyclinD-CDK6 regulate the G0-G1 transition in quiescent cells and the early G1 phase transition in proliferating cells by phosphorylating the tumor suppressor reti- 
noblastoma protein $(\mathrm{Rb})$ and thus activating the transcription factor E2F [7]. Activated E2F regulates transcription through G1/S phase by coordinating gene transcription of cell cycle progression-relevant proteins [8] (Fig. 1a). The endogenous tumor suppressor p16INK4a (p16) blocks CDK4/6 and causes a permanent G1 phase arrest [9]. Hence, the CDK4/6 inhibitor LEE011 (Novartis, Basel) offers a very promising molecular targeting approach by selectively downregulating the proliferationassociated cyclinD-CDK4/6-Rb axis (Fig. 1b). In various studies, the small molecule CDK4/6 inhibitor LEE011 has been shown to have antiproliferative characteristics with only weak side effects in comparison to previous nonselective CDK inhibitors [10]. Currently, a clinical phase 2 trial with LEE011 is recruiting patients with advanced NETs of foregut origin (NCT02420691). Therefore, the phylogenetic homologues CDK4 and CDK6 [11] represent promising novel molecular targets for therapeutic NET treatments. Here, we investigate the effects of the CDK4/6 inhibitor LEE011 on different NET cell lines in vitro.

\section{Materials and Methods}

\section{Materials}

Ribociclib (LEE011) and everolimus (Rad001) were provided by Novartis (Basel, Switzerland). 5-Fluorouracil (5-FU) was purchased from Selleckchem (Houston, TX, USA). Everolimus and 5-FU were diluted in dimethyl sulfoxide (DMSO; $10 \mathrm{mM}$ stock solution; Sigma, D8418). LEE011 was diluted in deionized water. Dulbecco's Modified Eagle's Medium - NutrientMixture F-12 (1: 1) (DMEM/F12) and penicillin/streptomycin were obtained from Gibco/Invitrogen (Karlsruhe, Germany). RPMI medium (with Lglutamine, $\mathrm{NaCO}_{3}$ ) and phosphate-buffered saline (PBS) were purchased from Sigma, whereas trypsin-EDTA $(10 \times)$ was acquired from PAA Laboratories (Cölbe, Germany). Fetal bovine serum (FBS) and amphotericin B were acquired from Biochrom (Berlin, Germany).

\section{Cell Culture}

The human pancreatic NET (pNET) cell line BON1 [12] (kindly provided by Prof. R. Göke, Marburg, Germany) and the pancreatic islet tumor cell line QGP1 (acquired from JCRB Cell Bank [Japanese Collection of Research Bioresources Cell Bank]) [13] were grown in DMEM/F12 (1:1) supplemented with 10\% FBS, 1\% penicillin/streptomycin and $0.4 \%$ amphotericin B. Human bronchopulmonary neuroendocrine NCI-H727 (in all figures named H727) tumor cells [14] (acquired from ATCC, Manassas, VA, USA) and human midgut carcinoid GOT1 cells [15] (kindly provided by Prof. O. Nilsson, Sahlgrenska University Hospital, Göteborg, Sweden) were grown in RPMI medium supplemented with $10 \%$ FBS, $1 \%$ penicillin/streptomycin and $0.4 \%$ amphotericin B. The GOT1 culture medium was additionally supplemented with $5 \mu \mathrm{g} / \mathrm{mL}$ apo-transferrin and $0.135 \mathrm{IU} / \mathrm{mL}$ insulin. All human neu- roendocrine cell lines were received and cultured as described previously $[16,17]$. The cells were tested and determined to be mycoplasma free and incubated at $37^{\circ} \mathrm{C}$ and $5 \% \mathrm{CO}_{2}$.

\section{Cell Viability Assessment}

Cells were counted (Cellcounter Countess, Invitrogen, Germany), seeded, and grown for $24 \mathrm{~h}$ in 96-well plates at densities of 1,500 (BON1), 2,000 (QGP1 and NCI-H727), and 30,000 (GOT1) cells per well. After $24 \mathrm{~h}$, the cells were treated in $10 \% \mathrm{FBS}$ with different concentrations of LEE011 alone and in combination with $10 \mathrm{nM}$ everolimus or $5 \mu \mathrm{M} 5$-FU, as previous studies had shown significant effects for the respective substance concentrations in NET cells in vitro $[16,18]$. Metabolic activity was measured with a CellTiter $96^{\circledR}$ $\mathrm{Aq}_{\text {ueous }}$ One Solution cell viability assay (Promega, Madison, WI, USA) after 72 and $144 \mathrm{~h}$ of incubation. Then, the treated cells were incubated for $4 \mathrm{~h}$ with CellTiter 96 solution, and the absorbance was determined at $490 \mathrm{~nm}$ using an ELISA plate reader (Orion II; Berthold Detection Systems, Pforzheim, Germany).

\section{Cell Cycle Analysis by Flow Cytometric Analysis}

Cell cycle distribution was analyzed following the quick method from Nature Protocols "Analysis of Apoptosis by Propidium Iodide Staining and Flow Cytometry” [19] (BD Accuri C6 Analysis). Cells were cultured in 6 -well plates $\left(4 \times 10^{5} \mathrm{BON} 1\right.$ cells/well and $5 \times 10^{5}$ QGP1 and NCI-H727 cells/well) for $24 \mathrm{~h}$ in complete medium. After $24 \mathrm{~h}$, the medium was replaced with fresh $10 \%$ FBS medium and incubated with $10 \mu \mathrm{M}$ LEE011 alone or in combination with $5 \mu \mathrm{M} 5$-FU or $10 \mathrm{nM}$ everolimus. After $72 \mathrm{~h}$, the cells were washed with PBS and treated with $300 \mu \mathrm{L}$ of trypsin at $37^{\circ} \mathrm{C}$ for $5 \mathrm{~min}$. Cells were collected and centrifuged at 2,000 rpm for $5 \mathrm{~min}$. After another wash cycle with PBS, the cells were centrifuged again. The pellets were resuspended in $350 \mu \mathrm{L}$ of propidium iodide, and $8 \mathrm{~h}$ later, 20,000 events from each sample were analyzed.

\section{Protein Extraction and Western Blotting}

For Western blot experiments, 450,000 (BON1) and 600,000 (QGP1 and NCI-H727) cells were seeded in 10-cm plates and grown for $24 \mathrm{~h}$ in complete medium. Then, the medium was replaced with fresh $10 \%$ FBS medium, and cells were incubated with different concentrations of LEE011 (500 nM and $10 \mu \mathrm{M})$ alone or in combination with 5 -FU $(5 \mu \mathrm{M})$ and everolimus $(10 \mathrm{nM})$. The incubation times proceeded for up to $72 \mathrm{~h}$. After incubation, the cells were washed twice in cold PBS on ice and lysed in $500 \mu \mathrm{L}$ of lysis buffer (M-PER Mammalian Protein Extraction Reagent containing HALT protease and phosphatase inhibitor cocktail; Thermo Scientific, Rockford, IL, USA). Lysates were centrifuged at $13,000 \mathrm{rpm}$ for $10 \mathrm{~min}$. Supernatants were adjusted to the same protein concentration $(30-50 \mu \mathrm{g} / 50 \mu \mathrm{L}$ ) (Rotiquant Universal; Carl Roth, Karlsruhe, Germany) and denatured in sodium dodecyl sulfate (SDS) sample buffer $(0.25 \%$ Tris HCL, $40 \%$ glycerol, $2 \%$ SDS, 1\% dithiothreitol, and bromophenol blue, $\mathrm{pH} 8.8$ ). Equal amounts of protein were separated on an SDS polyacrylamide gel and electrotransferred for $60 \mathrm{~min}$ onto PVDF membranes (Immobilone; Millipore, Eschborn, Germany) using a semi-dry Western blot technique. After blocking in $2 \%$ skimmed milk powder, the membranes were incubated overnight at $4{ }^{\circ} \mathrm{C}$ in appropriate dilutions of primary antibodies against pAKT (Ser473) (\#4060), AKT (\#2920), pERK1/2 (Thr202/Tyr204) (\#4370), p4EBP1 (Ser65) (\#9451), 4EBP1 (\#9644), pRb (Ser780) (\#9307), pCDK1 (Tyr15) (\#4539), CDK1 (\#9116), cyclin B1 (\#12231), cyclin D1 (\# 2926),
60

Neuroendocrinology 2018;106:58-73 DOI: $10.1159 / 000463386$
Aristizabal Prada et al. 


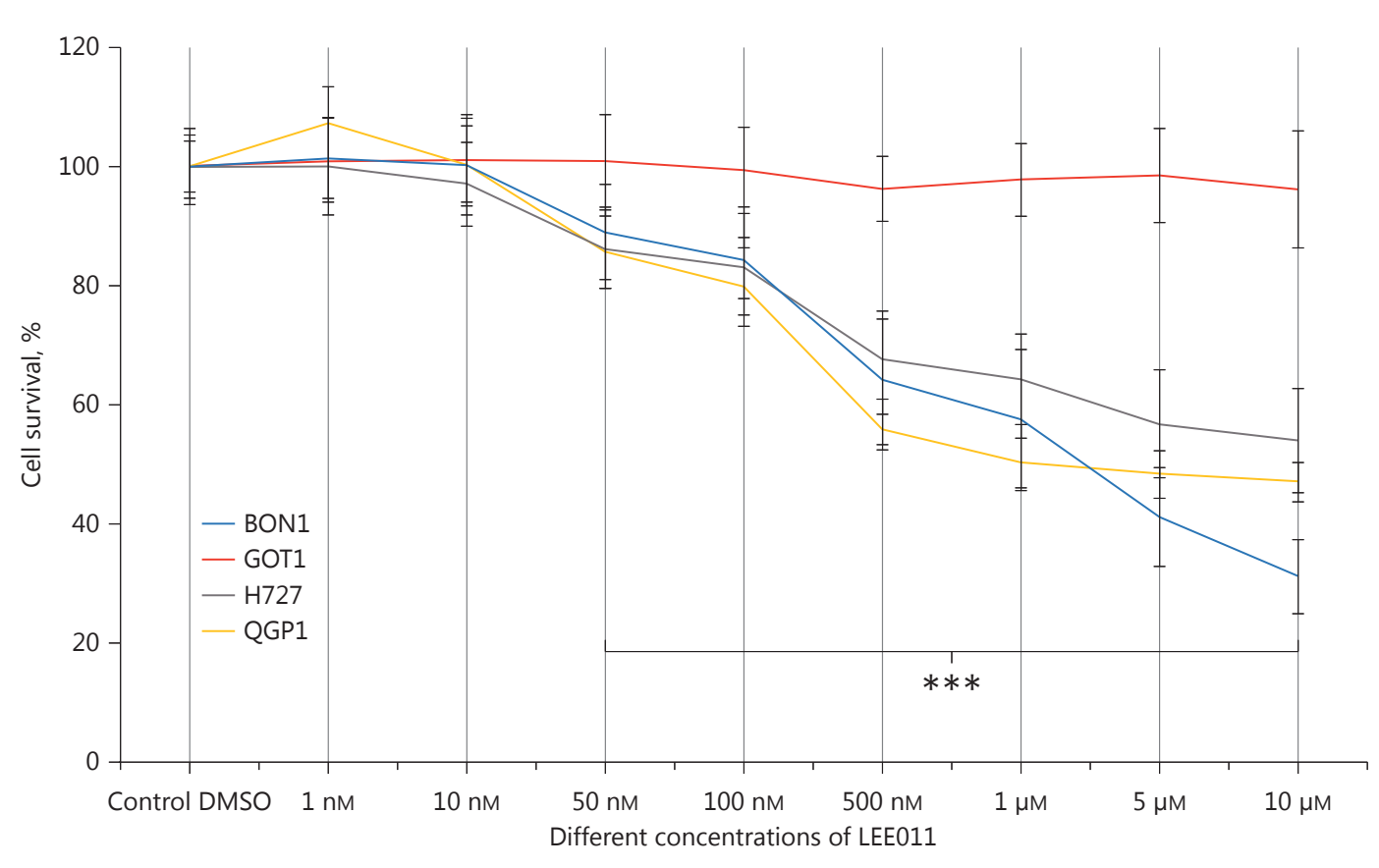

Fig. 2. The effect of different concentrations of LEE011 on cell survival of 4 different NET cell lines after $144 \mathrm{~h}$ of incubation. Human neuroendocrine pancreatic BON1, pancreatic islet QGP1, bronchopulmonary $\mathrm{H} 727$, and midgut GOT1 cells were incubated with LEE011 in a concentration range of $1 \mathrm{nM}$ to $10 \mu \mathrm{M}$ for $144 \mathrm{~h}$. The calculated means and standard deviation of at least 3 independent experiments are shown. Statistically significant differences in the results in comparison to control cells treated with DMSO $50 \mathrm{nM}$ to $10 \mu \mathrm{M}$ are represented by ${ }^{* * *} p<0.001$. Data are presented as mean $\pm \mathrm{SD}$. cyclin D3 (\#2936), CDK4 (\#12790), CDK6 (\#13331), Chk1 (\#2360), pChk2 (Ser19) (\#2666), pChk2 (Thr68) (\#6334), Chk2 (\#6334), Parp (\#9542), PCNA (\#2586) (all from Cell Signaling Technology, Danvers, MA, USA), p16 INK4A (ab151303) (Abcam, Cambridge, UK), Rb (\#614602) (Biolegend, San Diego, CA, USA), actin (A5441) (Sigma, St. Louis, CA, USA), and ERK1/2 (06-182) (Merck-Millipore, Darmstadt, Germany). After washing in TBS, the membranes were incubated with a peroxidase-conjugated secondary antibody $(1: 25,000)$ for $2 \mathrm{~h}$. The blots were washed and immersed in the chemiluminescent substrate Super Signal West Dura (Thermo-Scientific), and images were taken with an ECL Chemocam Imager (INTAS, Göttingen, Germany).

\section{Caspase-3/7 Activity Assay}

To measure the apoptotic activity, we used the Apo-One homogeneous caspase-3/7 assay kit (Promega, G7790). Therefore, we seeded 10,000 cells per well of each cell line and incubated for $72 \mathrm{~h}$ in different concentrations of LEE011 alone or in combination with $5 \mu \mathrm{M} 5$-FU and $10 \mathrm{nM}$ everolimus. Cells were incubated for $72 \mathrm{~h}$, and caspase-3/7 activity was assessed following the manufacturer's instructions.

\section{Statistical Analysis}

The results are displayed as the mean \pm standard deviation of the mean (SD) of at least 3 independently performed experiments.

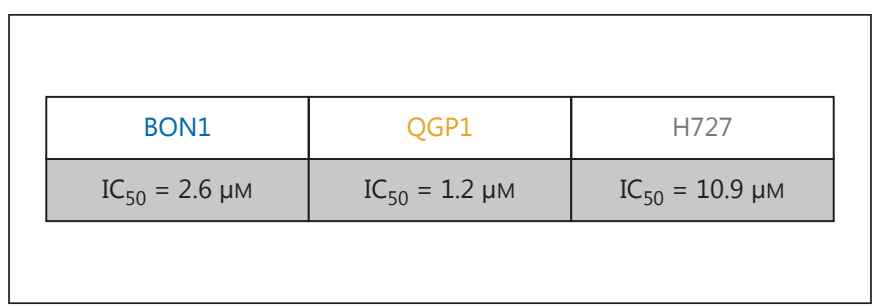

Fig. 3. The $50 \%$ inhibitory concentration $\left(\mathrm{IC}_{50}\right)$ of LEE011 in 3 different NET cell lines after $144 \mathrm{~h}$ of incubation.

Each cell viability experiment consisted of at least 6 samples per substance concentration and incubation period. A priori tests considering the normal distribution and homogeneity of variances were performed applying the Kolmogorov-Smirnov test and Levene's test using the SPSS statistical package (version 13.0 for Windows, SPSS Inc., Chicago, IL, USA). When parametric criteria were met, an ANOVA comparison of means with a post hoc Tukey test or a 2-tailed $t$ test was performed; when nonparametric criteria were met, a Kruskal-Wallis test was performed followed by a Mann-Whitney test. Statistical significance was assessed at $p<$ 0.05 . 


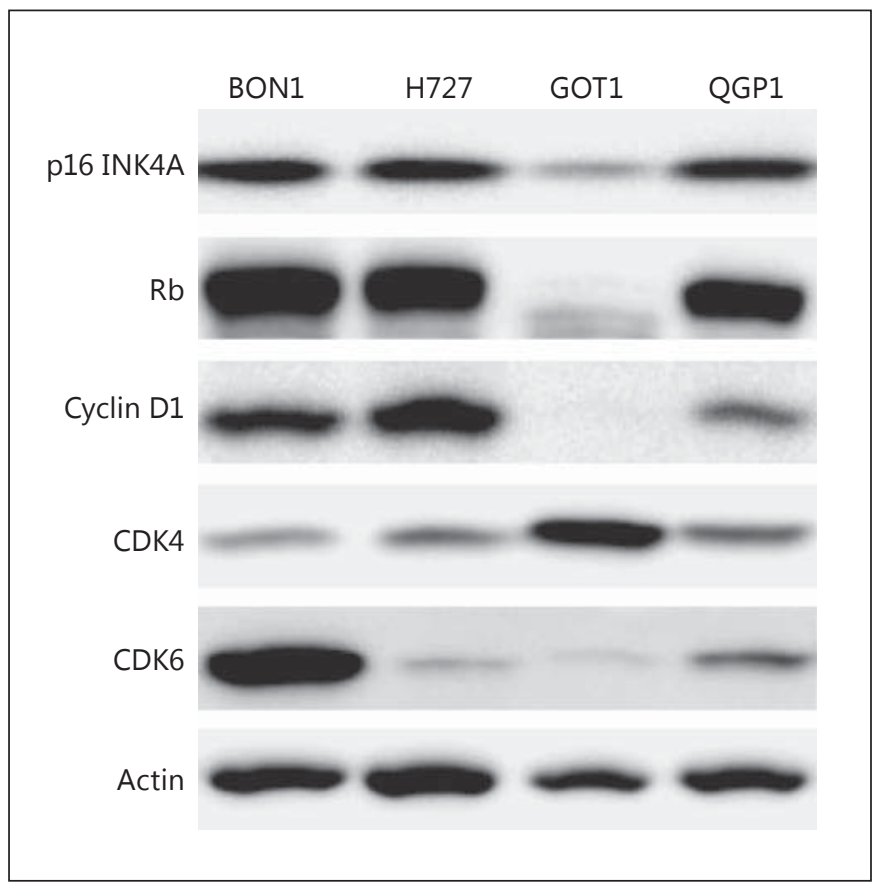

Fig. 4. Basal expression levels of proteins from the cyclinD$\mathrm{CDK} 4 / 6-\mathrm{Rb}$ axis in all $4 \mathrm{NET}$ cell lines. The expression of $\mathrm{p} 16, \mathrm{Rb}$, cyclin D1 CDK4, and CDK6 was evaluated by Western blot analysis. A representative blot out of 3 independently performed experiments is shown.

\section{Results}

LEE011 Inhibits Cellular Proliferation in Three out of Four NET Cell Lines

Neuroendocrine pancreatic BON1 cells, pancreatic islet QGP1 NET cells and bronchopulmonary NCI-H727 NET cells showed significant treatment susceptibility in a time- and dose-dependent manner (Fig. 2). GOT1 cells showed treatment resistance at all concentrations and incubation times tested. All 4 cell lines were incubated with LEE011 at a concentration range of $1 \mathrm{nM}$ to $10 \mu \mathrm{M}$. The most notable results were obtained after $144 \mathrm{~h}$ of incubation with LEE011, where significant differences in all 3 cell lines in comparison to the Control DMSO-treated cells were reached with a concentration of only $50 \mathrm{nM}$. At a maximum concentration of $10 \mu \mathrm{M}$, cell viability decreased in BON1 cells to $31.08 \pm 6.13 \%$, in QGP1 cells to $47 \pm 3.28 \%$, and in NCI-H727 cells to $53.90 \pm 8.74 \%$. In QGP1 cells, an efficacy limit with a plateau effect was reached at a concentration of $1 \mu \mathrm{M}$. Further concentration augmentation did not yield a significant survival de- crease enhancement in QGP1 cells. The most sensitive cells towards the treatment, following the $\mathrm{IC}_{50}$ values of each cell line after $144 \mathrm{~h}$ of incubation with LEE011 (1 $\mathrm{nM}$ to $10 \mu \mathrm{M})$, were QGP1 $\left(\mathrm{IC}_{50}=1.2 \mu \mathrm{M}\right)$, followed by BON1 cells $\left(\mathrm{IC}_{50}=2.6 \mu \mathrm{M}\right)$ and NCI-H727 $\left(\mathrm{IC}_{50}=10.9\right.$ $\mu \mathrm{M})$ (Fig. 3).

\section{Sensitivity to LEE011 Treatment Depends on $R b$ and Cyclin D1 Expression}

Western blot analysis showed different baseline expression patterns of the cyclinD-CDK4/6-Rb axis in all 4 NET cell lines (Fig. 4). The tumor suppressor p16, Rb and cyclin D1 were stably expressed in neuroendocrine pancreatic BON1, pancreatic islet QGP1 and bronchopulmonary NCI-H727 cells, whereas they were poorly expressed in GOT1 cells. CDK4 was very strongly expressed in GOT1 cells and less strongly expressed but present in all others. BON1 cells showed the highest CDK6 expression, followed by QGP1, NCI-H727, and GOT1 cells.

\section{LEE011 Causes G1 Phase Cell Cycle Arrest}

In all 3 NET cell lines, flow cytometric analysis demonstrated that LEE011 caused a dose-dependent increase in G1 phase cell cycle arrest after incubation with cells for $72 \mathrm{~h}$ (Fig. 5). In BON1 (Fig. 5a) and QGP1 (Fig. 5b) cells, a significant increase in G1 phase cell cycle arrest was observed with concentrations as low as $1 \mu \mathrm{M}$ and observed in NCI-H727 (Fig. 5c) cells with concentrations as low as $100 \mathrm{nM}$. At a maximum concentration of $10 \mu \mathrm{M}$, the mean G1 phase percent of BON1 (Fig. 5a), QGP1 (Fig. 5b), and NCI-H727 (Fig. 5c) cells increased to $77.5 \pm 2.1,89.9 \pm$ 0.9 , and $84.4 \pm 4.9 \%$, respectively. Consequently, the mean percent of cells in the G2 and S cell cycle phase significantly decreased in all 3 cell lines (Fig. 5).

\section{Combined Treatment with LEE011, 5-FU and \\ Everolimus Showed More Efficacy Than \\ Single-Substance Treatment in Decreasing NET \\ Cell Survival}

For all 3 NET cell lines tested, the combined treatment led to significantly more effective results in mediating cell survival than single-substance treatment (Fig. 6). At all incubation times and in all 3 cell lines, the combined treatment with LEE011 (500 nM) and everolimus (10 nM) showed significantly higher decreases in cell survival than each single-substance treatment (Fig. 6). The combined treatment with 5-FU was more effective only at some of the tested incubation times and in some of the cell lines (Fig. 6). In BON1 cells, the combined treatment with 5 -FU $(5 \mu \mathrm{M})$ was only more effective after $72 \mathrm{~h}$ of
Aristizabal Prada et al. 
Fig. 5. Cell cycle analysis of BON1 (a), QGP1 (b), and H727 (c) cells with different concentrations of LEE011 (10 nM to $10 \mu \mathrm{M}$ ) after $72 \mathrm{~h}$ of incubation measured by flow cytometric analysis. The calculated means and standard deviation of at least 3 independent experiments are shown. Statistically significant differences in results in comparison to control cells treated with 10 $\mathrm{nM}$ to $10 \mu \mathrm{M}$ DMSO are represented by ${ }^{*} p<0.05{ }^{* *} p<0.01$, and ${ }^{* * *} p<0.001$. Data are presented as mean \pm SD.

Antitumoral Efficacy of LEE011
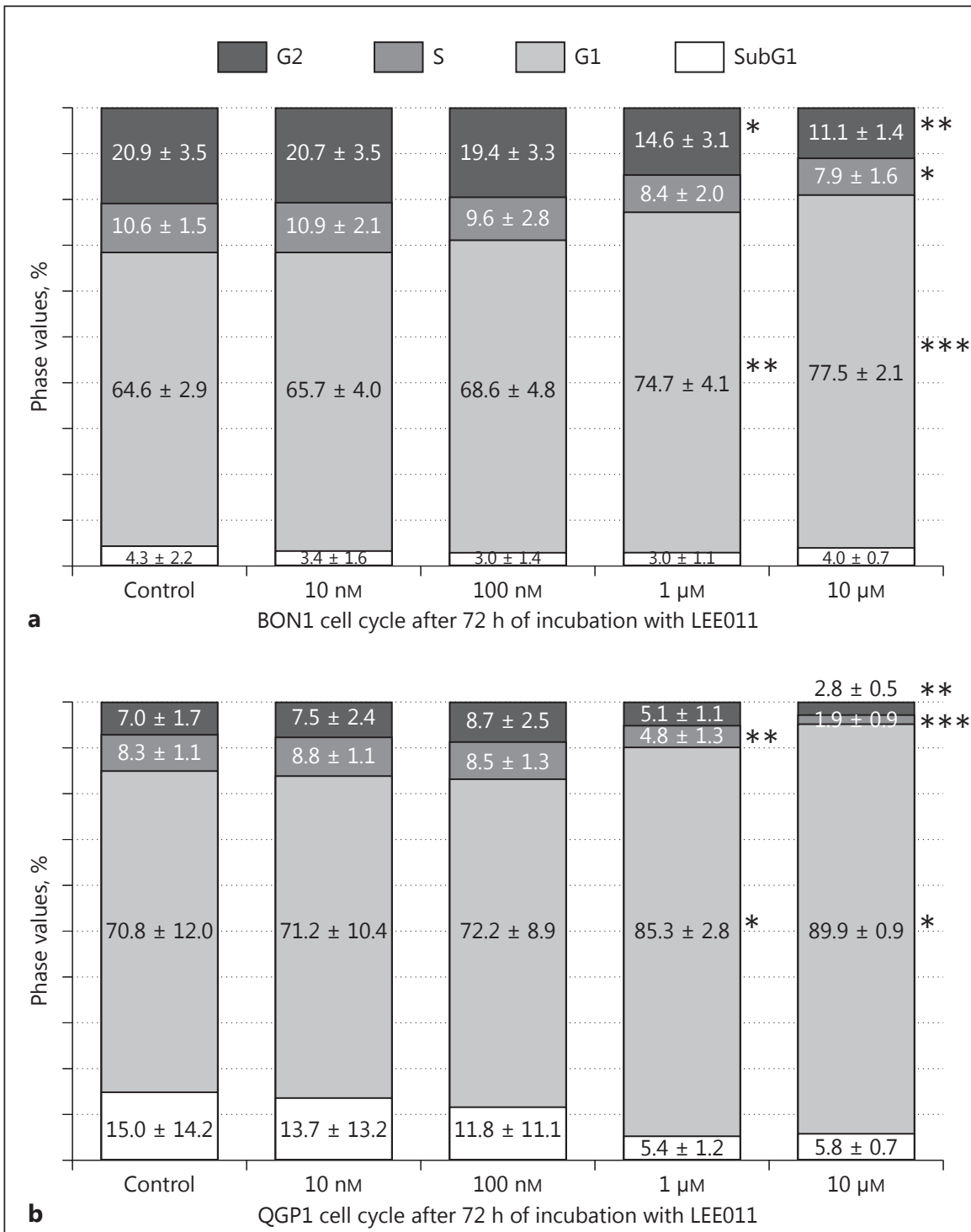

b

QGP1 cell cycle after $72 \mathrm{~h}$ of incubation with LEE011

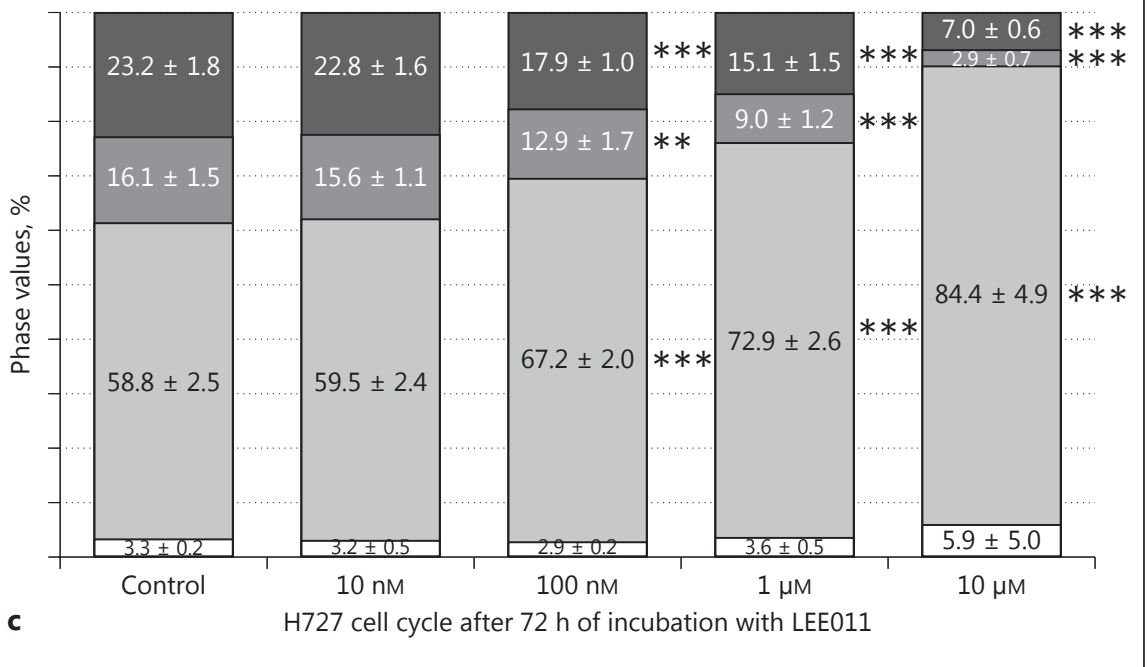

Neuroendocrinology 2018;106:58-73 DOI: $10.1159 / 000463386$ 


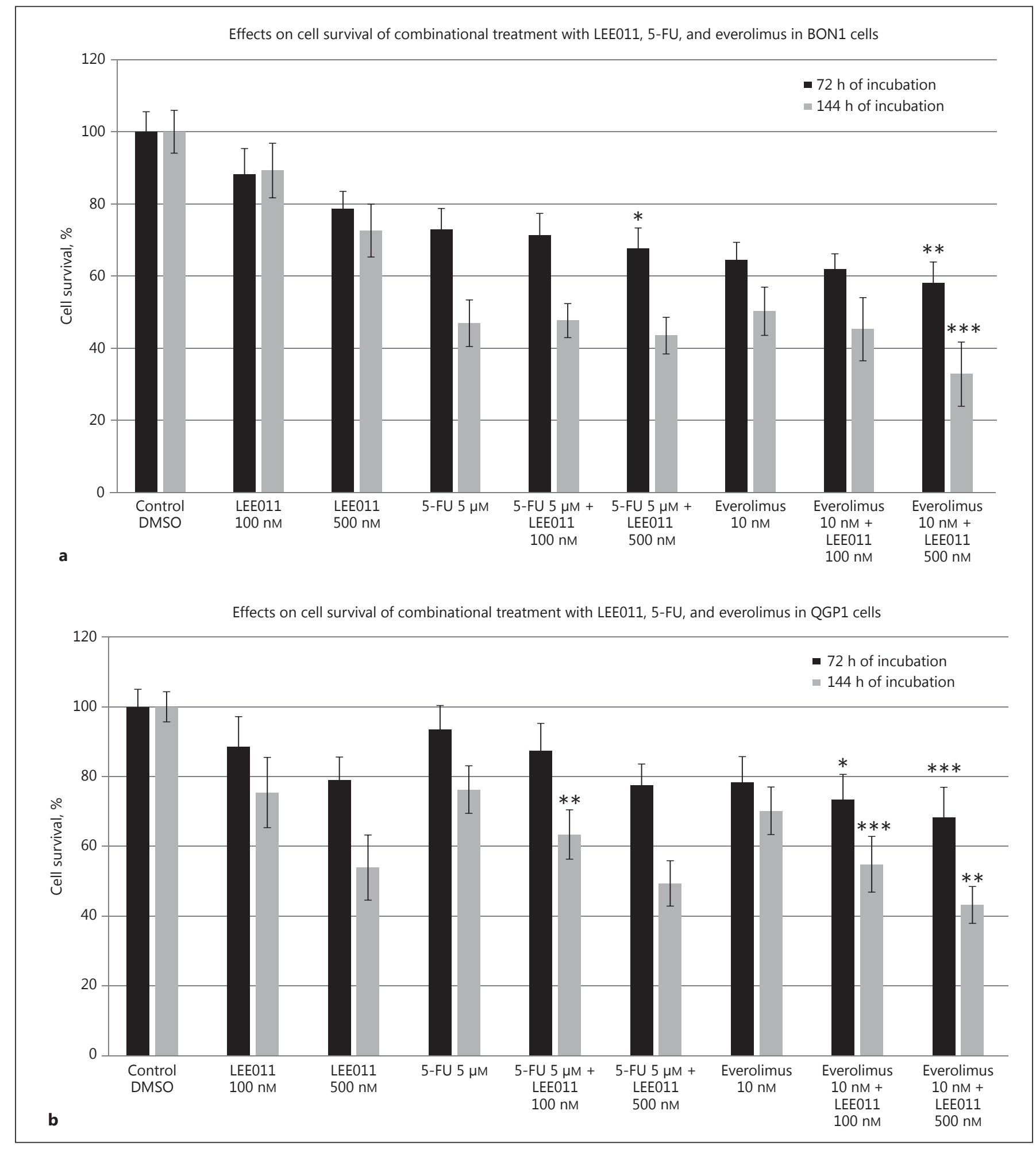

Fig. 6. Effect of LEE011 on cell survival of 4 different NET cell lines after 72 and $144 \mathrm{~h}$ of incubation. Human neuroendocrine pancreatic BON1 (a) and pancreatic islet QGP1 (b), and bronchopulmonary NCI-H727 (c) cells were incubated with LEE011 (100 and 500 $\mathrm{nM})$ alone and in combination with 5-FU $(5 \mu \mathrm{M})$ and everolimus
Neuroendocrinology 2018;106:58-73 DOI: $10.1159 / 000463386$
(10 nM) for 72 and $144 \mathrm{~h}$. The calculated means and standard deviation of at least 3 independent experiments are shown. Statistically significant differences in the results in comparison to singlesubstance treatments are shown; ${ }^{*} p<0.05,{ }^{* *} p<0.01,{ }^{* * *} p<$ 0.001 . Data are presented as mean \pm SD.

(Figure continued on next page.)
64
Aristizabal Prada et al. 


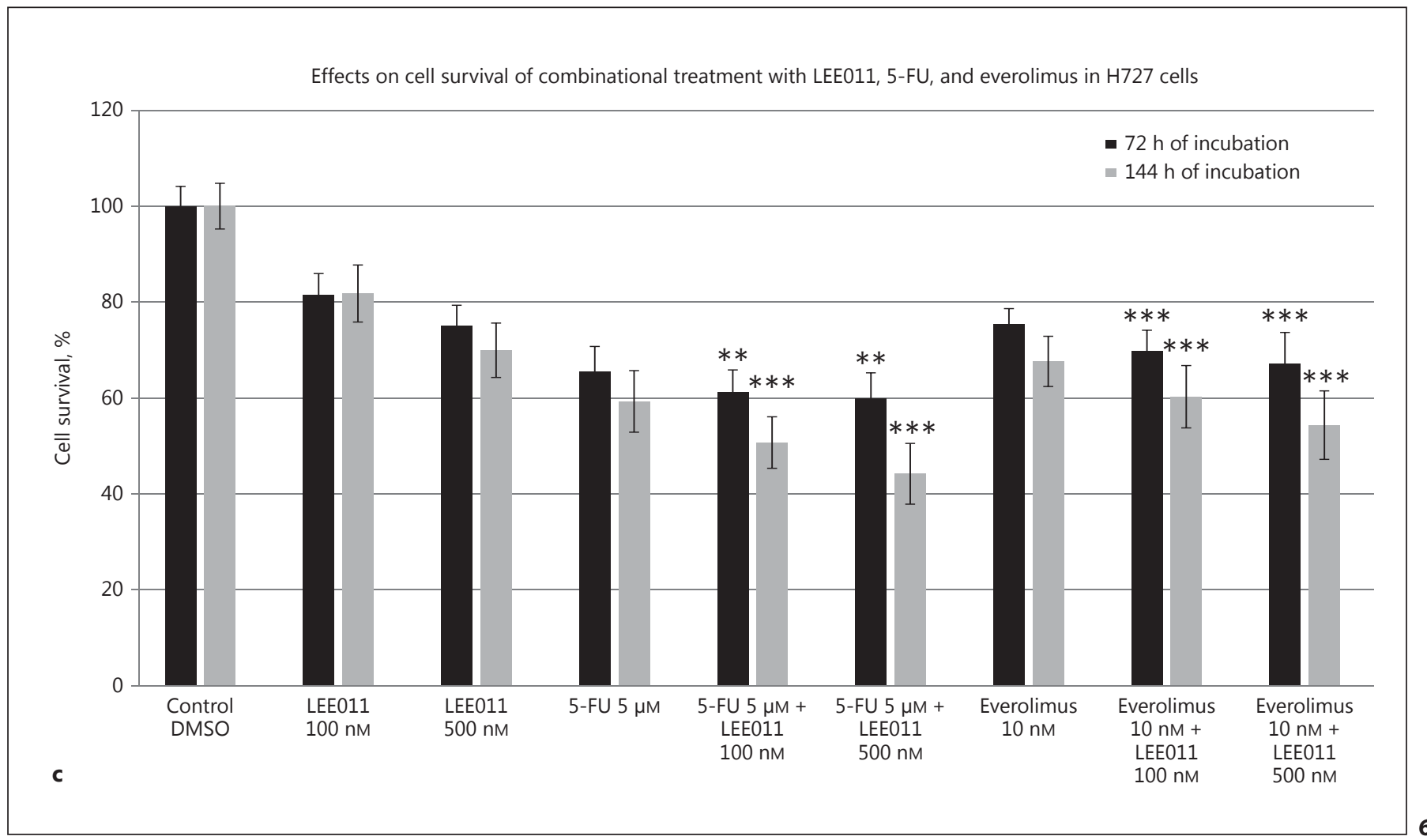

incubation with LEE011 (500 nM), and cell survival decreased to $67.62 \pm 5.73 \%$ (Fig. 6a). The combined treatment with LEE011 (500 nM) and everolimus (10 nM) in BON1 cells showed significantly enhanced antiproliferative effects after 72 and $144 \mathrm{~h}$, with a reduced mean cell survival of $58.07 \pm 5.85$ and $32.83 \pm 8.89 \%$, respectively (Fig. 6a). Furthermore, in QGP1 cells, the combined treatment with LEE011 (100 and $500 \mathrm{nM}$ ) and everolimus $(10 \mathrm{nM})$ was more effective than single-substance treatment at both incubation times (72 and $144 \mathrm{~h})$, and cell survival decreased to $73.33 \pm 7.29$ and $68.23 \pm 8.70 \%$ after $72 \mathrm{~h}$ of incubation and $54.85 \pm 7.98$ and $43.21 \pm$ $5.29 \%$ after $144 \mathrm{~h}$ of incubation, respectively (Fig. 6b). Whereas the combined treatment with 5-FU in QGP1 cells was only more effective at an incubation time of 144 $\mathrm{h}$ and LEE 011 concentration of $100 \mathrm{nM}$, with a mean survival of $63.40 \pm 7.06 \%$ (Fig. 6b). Only in bronchopulmonary NCI-H727 cells was the combination treatment with 5-FU more efficient than single-substance treatment at both incubation times and both concentrations of LEE011, with a mean survival of $61.28 \pm 4.59 \%$ (5-FU $5 \mu \mathrm{M}+$ LEE011 $100 \mathrm{nM})$ and $59.94 \pm 5.33 \%(5$-FU $5 \mu \mathrm{M}$ + LEE011 $500 \mathrm{nM}$ ) after $72 \mathrm{~h}$ and $50.72 \pm 5.36 \%$ (5-FU $5 \mu \mathrm{M}+$ LEE011 $100 \mathrm{nM}$ ) and $44.21 \pm 6.34 \%$ (5-FU $5 \mu \mathrm{M}$
+ LEE011 $500 \mathrm{nM}$ ) after $144 \mathrm{~h}$ of incubation (Fig. 6c). Again, in NCI-H727 cells, the combined treatment with everolimus showed significantly better results than the respective single-substance treatments, with a mean cell survival of $69.80 \pm 4.33 \%$ (everolimus $10 \mathrm{nM}+$ LEE011 $100 \mathrm{nM}$ ) and $67.21 \pm 6.46 \%$ (everolimus $10 \mathrm{nM}+$ LEE011 $500 \mathrm{nM}$ ) after $72 \mathrm{~h}$ of incubation and $60.28 \pm 6.51 \%$ (everolimus $10 \mathrm{nM}+$ LEE011 $100 \mathrm{nM}$ ) and $54.35 \pm 7.14 \%$ (everolimus $10 \mathrm{nM}+$ LEE011 $500 \mathrm{nM}$ ) after $144 \mathrm{~h}$ of incubation (Fig. 6c).

\section{LEE011 Blocks the Apoptotic Cell Death Mechanism through PARP and Caspase-3/7 Cleavage and Chk1 Downregulation}

Western blot analysis demonstrated the expression of PARP cleavage in human neuroendocrine pancreatic BON1, pancreatic islet QGP1 and bronchopulmonary NCI-H727 tumor cells when stimulated for $72 \mathrm{~h}$ with LEE011 (500 nM) alone and in combination with 5-FU $(5 \mu \mathrm{M})$ and everolimus ( $10 \mathrm{nM})$ (Fig. 7a). In all 3 cell lines, LEE011 alone decreased PARP cleavage, whereas 5-FU induced PARP cleavage in comparison to control cells treated with DMSO. Everolimus alone induced only low levels of PARP cleavage. LEE011 in combination with 


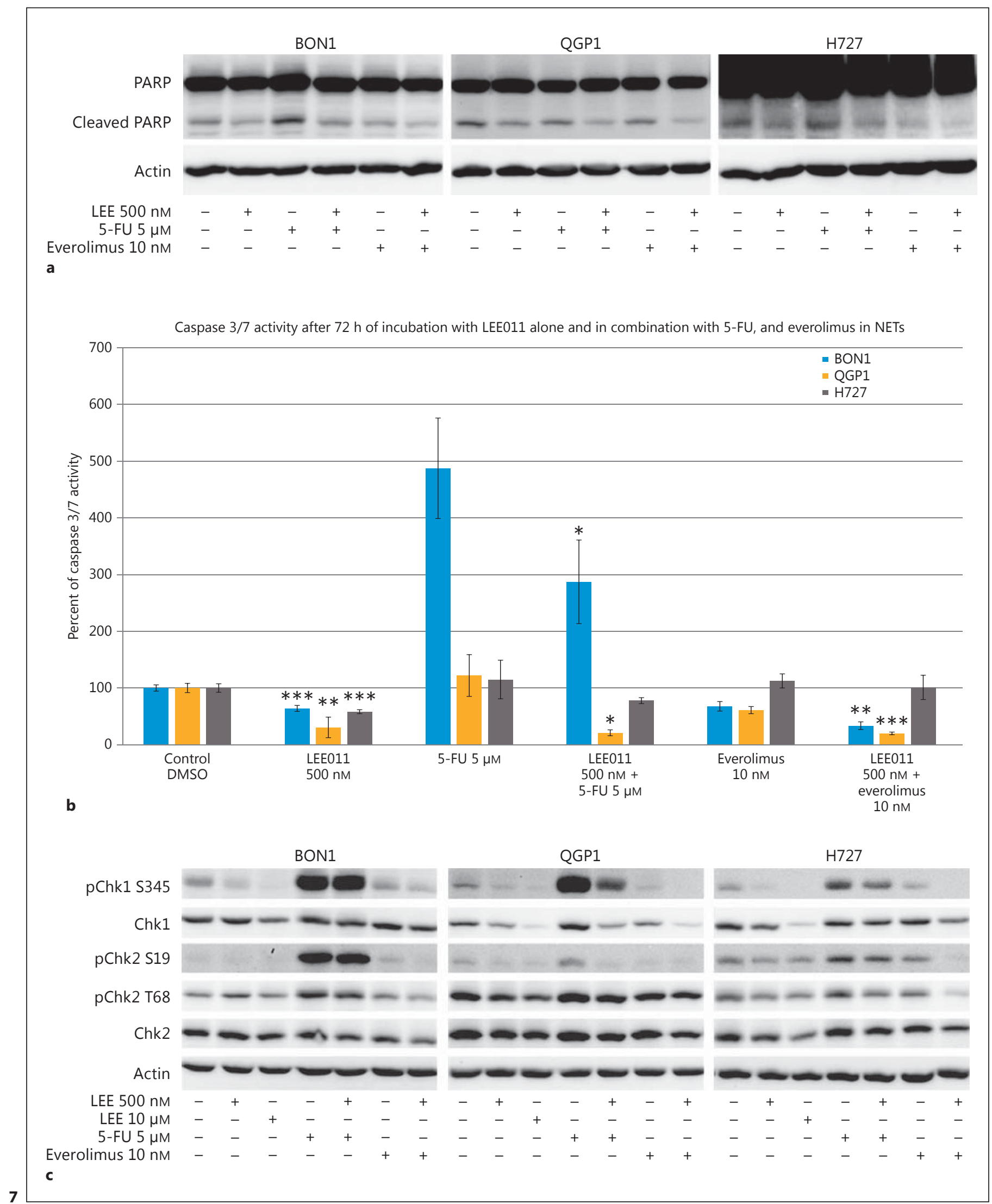

(For legend see next page.) 


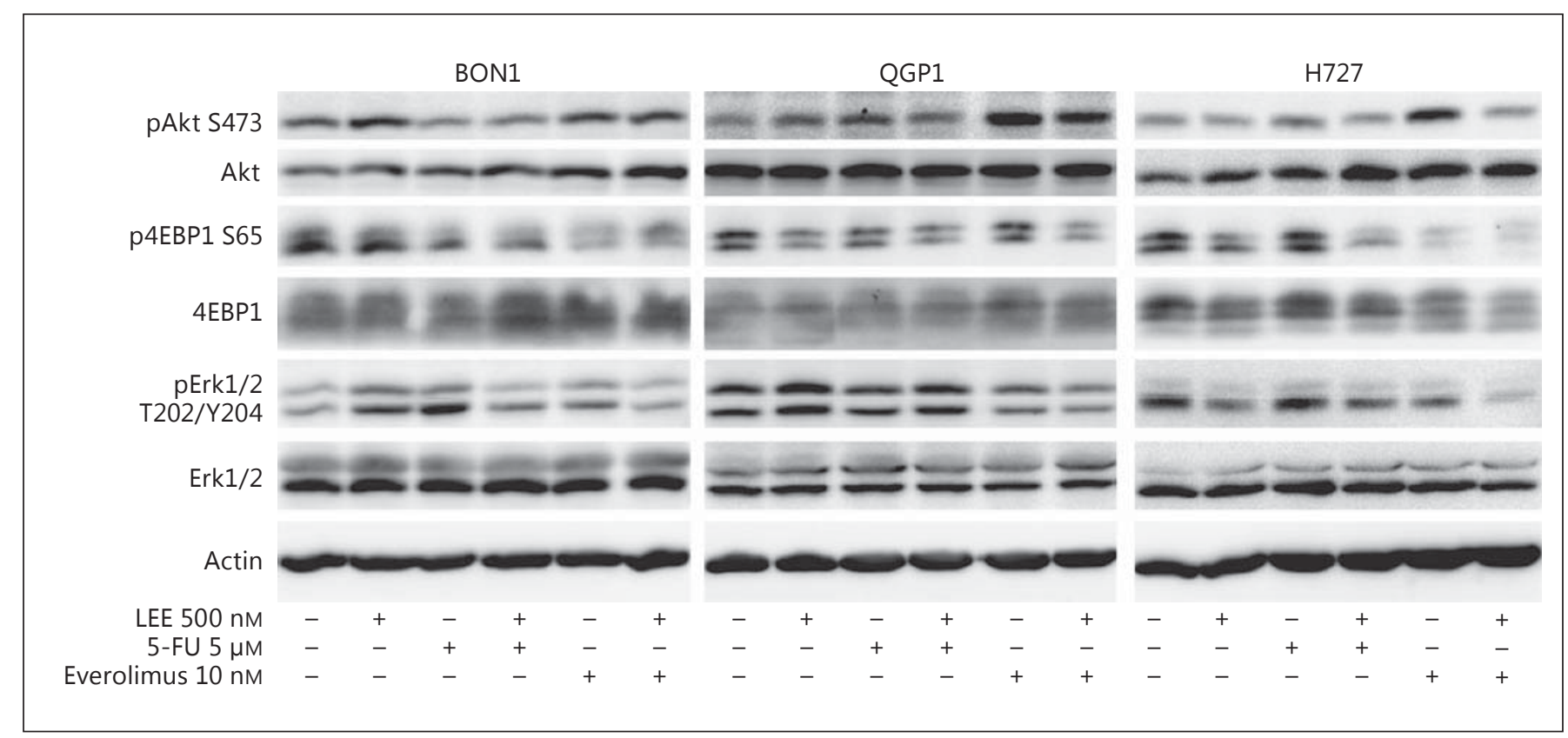

Fig. 8. The effects of LEE011 (500 nM) alone and in combination with 5-FU (5 $\mu \mathrm{M})$ and everolimus (10 nM) on components of the PI3K-Akt-mTOR and Ras-Raf-MEK-ERK signalling pathway in BON1, QGP1, and H727 cells after $72 \mathrm{~h}$ of incubation analyzed via Western blot. A representative blot from 3 independently performed experiments is shown.

5-FU antagonizes the PARP-cleaving effects of 5-FU in all 3 cell lines. Furthermore, the weak PARP-cleaving effects of everolimus are also counteracted by LEE011. Mean caspase- $3 / 7$ activity was significantly decreased in all 3 cell lines after $72 \mathrm{~h}$ of incubation with LEE011 (500 nM) (Fig. 7b). Again, LEE011 in combination with 5-FU was shown to significantly counteract the induced caspase-3/7 activity of 5-FU in BON1 and QGP1 cells (Fig. 7b). Everolimus alone did not induce caspase-3/7 activity, and the combination treatment with LEE011 and everolimus significantly lowered the already low cas-

Fig. 7. The effects of LEE011 (500 nM) alone and in combination with 5-FU $(5 \mu \mathrm{M})$ and everolimus $(10 \mathrm{nM})$ on caspase-3/7 activity and PARP cleavage after $72 \mathrm{~h}$ of incubation. a Western blot analysis of PARP cleavage in NETs. A representative blot from 3 independently performed experiments is shown. $\mathbf{b}$ Caspase-3/7 activity in BON1, QGP1, and H727 cells. The calculated means and standard deviation of at least 3 independent experiments are shown. Statistically significant differences in the results in comparison to single-substance treatments are shown; ${ }^{*} p<0.05$, ${ }^{* *} p<0.01,{ }^{* * *} p<0.001$. Data are presented as mean \pm SD. c Western blot analysis of Chk1 and Chk2 expression and phosphorylation in BON1, QGP1, and H727 cells. A representative blot from 3 independently performed experiments is shown.

Antitumoral Efficacy of LEE011 pase-3/7 activity in BON1 and QGP1 cells (Fig. 7b). LEE011 treatment alone and in combination with 5-FU and everolimus lowered the expression and phosphorylation of Chk1/2 in all 3 NET cell lines analyzed (Fig. 7c).

Combined Treatment with LEE011 and 5-FU or Everolimus Downregulates Two Major Proliferative Signaling Pathways in NETs: the PI3K-Akt-mTOR Pathway and Ras-Raf-MEK-ERK Pathway

Western blot analysis demonstrated the expression of PI3K-Akt-mTOR and Ras-Raf-MEK-ERK pathway components in human neuroendocrine pancreatic BON1, pancreatic islet QGP1 and bronchopulmonary NCIH727 tumor cells when stimulated for $72 \mathrm{~h}$ with LEE011 $(500 \mathrm{nM})$ alone and in combination with 5 -FU $(5 \mu \mathrm{M})$ or everolimus (10 nM) (Fig. 8). In BON1 and QGP1 cells, treatment with LEE011 alone phosphorylates Akt and Erk but dephosphorylates 4EBP1. In NCI-H727 cells, LEE011 alone has no effect on Akt phosphorylation, but p4EBP1 and pErk are downregulated. In all 3 cell lines, treatment with LEE011, 5-FU or everolimus resulted in unfavorable proproliferative phosphorylation of each component analyzed, but the combination treatment with 5-FU and LEE011 or everolimus and LEE011 an-

Neuroendocrinology 2018;106:58-73 DOI: $10.1159 / 000463386$ 


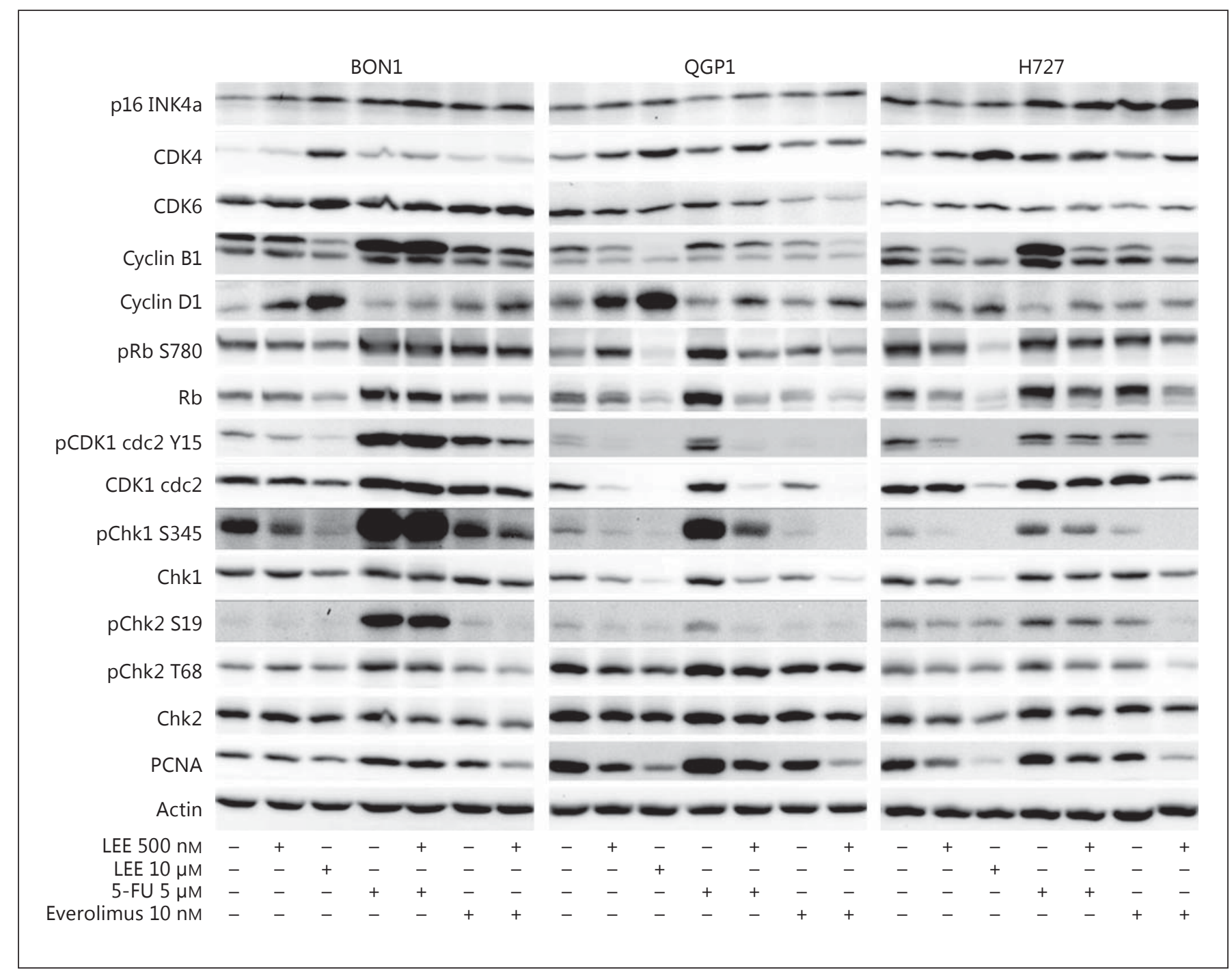

Fig. 9. The effects of LEE011 (500 nM) alone and in combination with 5-FU ( $5 \mu \mathrm{M})$ and everolimus (10 nM) on components of the cyclinD-CDK4/6-Rb axis, CDK1, and PCNA in BON1, QGP1, and H727 cells after $72 \mathrm{~h}$ of incubation analyzed via Western blot. A representative blot from 3 independently performed experiments is shown.

tagonized the unfavorable proproliferative phosphorylation of Akt, 4EBP1, and Erk when compared to the respective single-substance treatments. The treatment with LEE011 and everolimus, in particular, showed a strong effect on dephosphorylation of Erk in all 3 cell lines.

LEE011 Alone Downregulates the CyclinD-CDK4/ 6-Rb Axis and Combined Treatment with 5-FU or Everolimus Affects Cell Cycle-Regulating Components Western blot analysis revealed the expression level of cell cycle-relevant protein components in human neuro- endocrine pancreatic BON1, pancreatic islet QGP1 and bronchopulmonary NCI-H727 tumor cells when stimulated for $72 \mathrm{~h}$ with LEE011 $(10 \mu \mathrm{M})$ alone and in combination treatment with LEE011 (500 nM) and 5-FU ( $5 \mu \mathrm{M})$ or everolimus (10 nM) (Fig. 9). In all 3 cell lines, the endogenous CDK4/6 inhibitor p16 is upregulated in the combination treatments with 5-FU and everolimus. In BON1 and QGP1 cells, p16 is also upregulated upon single LEE011 $(10 \mu \mathrm{M})$ treatment. Possibly due to feedback mechanisms, CDK4 and CDK6 show an increase in expression with LEE011 $(10 \mu \mathrm{M})$ treatment. LEE011 at a 
concentration of $10 \mu \mathrm{M}$ decreases the cyclin $\mathrm{B} 1, \mathrm{pRb}, \mathrm{Rb}$, pCDK1 and CDK1 levels and increases the cyclin D1 level. In QGP1 and NCI-H727 cells, the combination treatment with everolimus cooperatively downregulated cyclin $\mathrm{B} 1, \mathrm{pRb}, \mathrm{Rb}, \mathrm{pCDK} 1$, and CDK1. In BON1 cells, the combination treatment with everolimus only cooperatively downregulated $\mathrm{Rb}$, but it attenuated the effects of everolimus on Cyclin B1, pCDK1 and CDK1. In all 3 cell lines, combined treatment with LEE011 and either 5-FU or everolimus attenuated the upregulation of cyclin D1. On the other hand, the 5-FU-mediated upregulation of cyclin B1, pRb, Rb, pCDK1, and CDK1 in QGP1 and NCI-H727 cells was attenuated by the combination treatment with LEE011 (500 nM). In all 3 cell lines, proliferating cell nuclear antigen (PCNA) was downregulated by either high concentrations of LEE011 $(10 \mu \mathrm{M})$ alone or by combination treatment with everolimus (10 $\mathrm{nM})$ and was attenuated in QGP1 and NCI-H727 cells treated with a combination of LEE011 (500 nM) and 5-FU (5 $\mu \mathrm{M})$.

\section{Discussion}

Therapeutic approaches against GEP-NETs are of limited efficacy, primarily due to their highly heterogeneous characteristics and the late-stage detection $[1,3]$; ergo, new strategies are urgently needed [4]. Nonspecific CDK inhibitors have been of limited efficacy in cancer treatment, and they have exhibited highly cytotoxic side effects [10]. The small molecule CDK4/6 inhibitor LEE011 has demonstrated antiproliferative characteristics with only mild side effects [10]. Therefore, in this in vitro study, we evaluated the novel and specific CDK 4/6 inhibitor LEE011 as a possible new molecular therapeutic strategy for NET treatment.

Our results suggest a relationship between the level of $\mathrm{Rb}$ and cyclin D1 expression and sensitivity to LEE011 treatment. The treatment-sensitive BON1, QGP1, and NCI-H727 cells showed elevated levels of Rb and cyclin D1 in comparison to LEE011 treatment-resistant GOT1 cells with barely detectable Rb and cyclin D1 levels (Fig. 4). Similar results were observed in an in vitro study with breast cancer cell lines, where CDK4/6 inhibitor (PD 0332991) treatment-sensitive cell lines also expressed a high cyclin D1 and Rb protein level [20]. A high expression level of the oncogene Cyclin D1 has been shown to have a pathogenic role in parathyroid tumorigenesis and GEP-NETs [21]. Hence, we suggest that GEP-NET treatment with LEE011 has a high therapeutic relevance. In addition, high cyclin D1 expression levels were detected

Antitumoral Efficacy of LEE011 in a study that included 92 patients with pNETs [22]. While loss of $\mathrm{Rb}$ is the reason for an augmented cell cycle and proliferation in some cancer types, in most cancer types, $\mathrm{Rb}$ remains in its wild-type state, including in NETs [23-26]. Rb-proficient wild-type cell lines depend mostly on cyclinD-CDK4/6 regulation for proliferation and are likely to be susceptible to CDK4/6 inhibitory treatments $[27,28]$. Typical carcinoids (100\%) and atypical carcinoids (79\%) of the lung exhibited Rb expression [24]. In our study, GOT1 cells showed only minimally detectable expression levels of Rb and cyclin D1 (Fig. 4). This stands in contrast to the clinical situation, as Rb and cyclin D1 were found to be highly expressed in various NET tumor samples $[21,22,24]$. A whole-exome comparison of primary well-differentiated NET samples versus BON, QGP1, and NCI-H727 cell lines showed substantial differences in mutation rates and mutation patterns $[29,30]$. These data $[29,30]$ demonstrate that available human NET cell lines might not adequately reflect the genetic and biological entities of well-differentiated NETs. Therefore, the in vitro results of our study must be interpreted and extrapolated with caution with regard to the clinical situation. In a xenograft mouse model, tumor growth of the QGP1 cell line was also inhibited by the CDK4/6 inhibitor PD 0332991 [22]. Many studies also reported a low p16 expression level with high CDK4/6 inhibitor susceptibility $[20,28,31]$. Here, we show that, on the one side, even a moderate expression of p16 (in BON1, QGP1, and NCI-H727 cells) (Fig. 4) does not comprise the antitumor efficiency of LEE011 (Fig. 2), and on the other side, low p16 expression in GOT1 cells (Fig. 4) did not sensitize cells to LEE011 treatment (Fig. 2). CDK4/6 inhibition was suggested to be effective in tumor entities with CDK4 overexpression or amplification [10]. In mice, the development of pancreatic islet or pituitary MEN-1 tumorigenesis required a functional $C d k 4$ gene [32]. Furthermore, Tang et al. [22], found an upregulation of CDK4 in pNETs, which led to subsequent phosphorylational inactivation of the retinoblastoma protein $(\mathrm{Rb})$, and they detected a $C d k 4$ or $C d k 6$ copy number increase in $19 \%$ of the cases in a genetic analysis of 26 pNETs. In our cell lines, CDK4 was expressed in all cell lines, but the expression levels of CDK4 and CDK6 were not markers for LEE011 treatment sensitivity (Fig. 4). We suggest that the treatment resistance of GOT1 cells arises due to deficient $\mathrm{Rb}$ expression and low expression of cyclin D1 (Fig. 4), which indicates that the cyclinD-CDK4/6- $\mathrm{Rb}$ axis is neglectable for GOT1 cell proliferation [10,27].

In neuroendocrine pancreatic BON1, pancreatic islet QGP1 and bronchopulmonary NCI-H727 cells, we ob-

Neuroendocrinology 2018;106:58-73 DOI: $10.1159 / 000463386$ 
served a time- and dose-dependent decrease in cellular survival with LEE011 treatment (Fig. 2) and found significant effects on NET cell cycle: A clear shift into G1 phase cell cycle arrest was observed in all 3 NET cell lines tested (Fig. 5). Similar results regarding a decrease in cell survival and G1 cell cycle arrest through inhibition of CDK4/6 with PD 0332991 were observed in breast cancer cell lines and ovarian cancer [20,28]. Wu et al. [33] 2011 also observed G1 phase cell cycle arrest due to CDK4 knock down in different lung cancer cells. Unfortunately, LEE011 treatment caused a dose-dependent increase in the expression of oncogenic cyclin D1 and CDK4/6, possibly due to feedback loop mechanisms, which could lead to de novo treatment resistance (Fig. 9). In estrogen-positive breast cancer cells, similar feedback mechanisms regarding cyclin D1 were detected, which led to cytostasis evasion [34]. In a HER2-positive breast cancer mouse model, dual targeting prevailed against an acquired cyclin D1-CDK4 upregulation-mediated treatment resistance [35]. Therefore, combination treatment strategies are a rational option, not only to enhance single substance efficacy but also to overcome possible treatment resistances and feedback loops.

The chemotherapeutic agent 5-FU is a clinically applied drug that causes cytotoxic DNA damage and activates apoptosis [36]. 5-FU and capecitabine are commonly used in the treatment of pNETs in various regimens, such as STZ/-FU, Cap/TEM, FOLFOX, or FOLFIRI [3739]. The combined treatment with LEE011 and 5-FU was a rational combination choice to maximize the antiproliferative efficacy, as the 2 drugs target different pathways. As a consequence, the combination treatment showed a significant enhancement in cellular growth decrease (Fig. 6). A similar outcome was shown in a study with human ovarian cancer cell lines, where the CDK4/6 inhibitor PD-0332991 enhanced the effects of chemotherapy [28]. In addition, the combination treatment downregulated oncogenic components of the PI3K-Akt-mTOR pathway and Ras-Raf-MEK-ERK pathway (Fig. 8). Many studies indicate the importance of the Ras-Raf-MEKERK and the PI3K-Akt-mTOR molecular signaling pathway for NET cell growth, invasion, and proliferation [16, 40-46]. In addition, 5-FU showed cooperative downregulating effects with LEE011 on cell cycle components such as oncogenic cyclin D1 (Fig. 9), which is often overexpressed in GEP-NETs and influences tumorigenesis and cell proliferation in NETs $[21,22]$. Unfortunately, the ability of 5-FU to activate apoptotic mechanisms of cell death due to DNA damage [36] seems to be attenuated by LEE011, as evidenced by the downregulation of proapop- totic PARP cleavage (Fig. 7a) and caspase-3/7 activity (Fig. 7b). The DNA damage response induces 2 cell cycle checkpoint kinases (Chk1 and Chk2) at G2/M and G1/S phase transition, respectively [47]. LEE011 decreases the levels of Chk1/2 and their phosphorylation in NETs, and, as a result, the cell cycle is permanently arrested (Fig. 7c). Downregulation of Chk1 was also observed in a study with PD0332991 [48]. Although active Chk1 inhibition is correlated with an enhancement of 5-FU cytotoxicity [49], in combination with LEE011 the downregulation of Chk $1 / 2$ is due to the G1 phase cell cycle arrest rather than to specific Chk1-inhibiting effects, proving again the antagonistic effects of LEE011 + 5-FU; CDK4/6 inhibition causes cell cycle arrest without passing beyond the restriction point of Chk activation, hence abrogating the need for negative regulation of mitosis entry [50]. Given our data, we assume that the permanent G1 phase cell cycle arrest as a consequence to CDK4/6 inhibition by LEE011 might rescue the cells from undergoing apoptotic cell death in response to 5-FU treatment. Similar results are shown in a study with triple-negative breast cancer models, where CDK4/6 inhibition counteracted the cytotoxic response of doxorubicin, and in an in vivo study, where the DNA-damaging effects of carboplatin were also antagonized by the CDK4/6 inhibitor [48, 51, 52]. Hence, we recommend further investigation of the effects of 5-FU in combination with CDK4/6 inhibitors to clarify possible antagonizing effects, and we expect the ongoing phase 1 study with paclitaxel and the CDK4/6 inhibitor palbociclib to examine this convoluted matter in the clinic (NCT01320592).

The PI3K-Akt-mTOR pathway is an important and often constitutively activated pathway in NETs $[16,46]$. The mTOR inhibitor everolimus has been investigated in NETs in several clinical phase 3 trials [53]. Everolimus has been approved for the treatment of advanced pNETs [54-57] and for the treatment of gastrointestinal NETs and lung NETs [53], and it is one of the established treatment options according to ENETS guidelines [53]. Single-substance treatment with everolimus has been shown to lead to resistance mechanisms in many tumor entities, including pNETs [58-61]. Dual-targeted therapy approaches to overcome possible resistance mechanisms and feedback loops have shown promising results in NETs [40, 62]. In PI3K inhibitor-resistant cancer cells, combined treatment with a CDK4/6 inhibitor re-sensitized cancer cells to PI3K inhibition [63]. The PI3K-AktmTOR pathway is also a crucial molecular signaling pathway in promoting cyclinD-CDK4/6-dependent proliferation, as it converges into the cell cycle pathway at that
70

Neuroendocrinology 2018;106:58-73 DOI: $10.1159 / 000463386$
Aristizabal Prada et al. 
point [64]. Combined treatment with the mTORC1downregulating everolimus significantly enhanced the decrease in cellular survival in all NET cell lines tested (Fig. 6). Similar effects on cell survival were obtained in a study with breast cancer, where the combination of a CDK4/6 inhibitor with a PI3K inhibitor synergistically inhibited tumor cell viability [63]. Additionally, the combination treatment with everolimus downregulated the oncogenic PI3K-Akt-mTOR pathway and the Ras-RafMEK-ERK pathway (Fig. 8) and showed cooperative effects on the downregulation of cell cycle components (Fig. 9). Similar to the combination treatment with 5-FU, the combination of LEE011 and everolimus also showed cooperative effects in blocking oncogenic cyclin D1 (Fig. 9) [21, 22]. In addition, the endogenous CDK4/6 inhibitor p16 is upregulated upon combined LEE011 and everolimus treatment in all 3 cell lines (Fig. 9), supporting the exogenous CDK4/6 inhibition of LEE011. Furthermore, the combination treatment with everolimus and LEE011 showed no crucial antagonizing effects on apoptotic cell death mechanisms (Fig. 7). mTOR activity has been shown to have little association with apoptotic signalling mechanisms, and only high doses of everolimus could induce apoptotic cell death mechanisms in NETs $[16,65]$. In addition, the combination treatment (LEE011 + everolimus)-mediated decrease in Chk expression and phosphorylation (Fig. 7c) had no appreciable impact on treatment efficiency, as everolimus is a molecular targeting substance, not a DNA damaging agent [66]. Furthermore, the combination treatment with everolimus showed strong agonistic effects with LEE011 in PCNA inhibition (Fig. 9). PCNA is a DNA polymerase accessory protein that is implicated in different cellular processes, such as DNA replication, DNA repair, and cell cycle control [67]. PCNA has been found to actively bind to some Cyclins and their corresponding kinases to support cell cycle progression and DNA replication [67, 68]. Inhibition of PCNA due to either endogenous p21 or exogenous inhibitors leads to immediate cell cycle arrest $[69,70]$. Interestingly, everolimus was shown to increase G1 phase cell cycle arrest in NET cells, assuming a possible reinforcing effect for combination with CDK4/6 inhibitors such as LEE011 [16]. Current clinical phase 1b studies are investigating the combination of LEE011 and everolimus in patients with breast cancer (NCT01857193 and NCT02732119). Taken together, our data regarding the combination treatment with LEE011 and everolimus in NETs in vitro suggest that this dual-targeting strategy may be an effective regimen for a novel therapeutic strategy against NETs.

Antitumoral Efficacy of LEE011

\section{Conclusion}

We demonstrated that the highly selective CDK4/6 inhibitor LEE011 exerts significant antitumoral efficacy in NET cell lines in vitro, either alone or in a dual-targeting approach together with 5 -fluorouracil or everolimus. The small molecule CDK4/6 inhibitor LEE011 effectively blocks cellular proliferation through downregulation of the cyclinD-CDK4/6-Rb axis. Thus, CDK4/6 inhibition with LEE011 might be an effective new therapeutic regimen for NETs. Currently, a clinical phase 2 trial with LEE011 is recruiting patients with advanced NETs of foregut origin (NCT02420691), and another clinical phase 2 trial is recruiting patients with CDK4/6 pathwayactivated tumors (NCT02187783).

\section{Acknowledgements}

This work contains parts of the unpublished doctoral thesis of E.T. Aristizabal Prada. The manuscript was edited for proper English diction, grammar, punctuation, spelling, and overall style by native English-speaking editors at American Journal Experts.

\section{Disclosure Statement}

C.J. Auernhammer has received research contracts (Ipsen, Novartis), lecture honorarium (Ipsen, Novartis, Pfizer, Amgen, Roche, Falk), and advisory board honorarium (Novartis). The authors declare that there is no conflict of interest that would prejudice the impartiality of this scientific work.

\section{Funding Sources}

E.T. Aristizabal Prada received a scholarship from FAZIT-Stiftung (http://www.fazit-stiftung.de). This study was funded by an unrestricted research grant from Novartis Pharma GmbH, Nürnberg, Germany.

\footnotetext{
References $\quad 1$ Modlin IM, Oberg K, Chung DC, Jensen RT, de Herder WW, Thakker RV, Caplin M, Delle Fave G, Kaltsas GA, Krenning EP, Moss SF, Nilsson O, Rindi G, Salazar R, Ruszniewski P, Sundin A: Gastroenteropancreatic neuroendocrine tumours. Lancet Oncol 2008;9:6172.

2 Modlin IM, Gustafsson BI, Moss SF, Pavel M, Tsolakis AV, Kidd M: Chromogranin A - biological function and clinical utility in neuro endocrine tumor disease. Ann Surg Oncol 2010;17:2427-2443.
}

Neuroendocrinology 2018;106:58-73 DOI: $10.1159 / 000463386$ 71 
3 Schimmack S, Svejda B, Lawrence B, Kidd M, Modlin IM: The diversity and commonalities of gastroenteropancreatic neuroendocrine tumors. Langenbecks Arch Surg 2011;396: 273-298.

4 Auernhammer CJ, Goke B: Therapeutic strategies for advanced neuroendocrine carcinomas of jejunum/ileum and pancreatic origin. Gut 2011;60:1009-1021.

5 Peyressatre M, Prevel C, Pellerano M, Morris MC: Targeting cyclin-dependent kinases in human cancers: from small molecules to peptide inhibitors. Cancers 2015;7:179-237.

6 Obaya AJ, Sedivy JM: Regulation of cyclinCdk activity in mammalian cells. Cell Mol Life Sci 2002;59:126-142.

7 Sherr CJ, Roberts JM: CDK inhibitors: positive and negative regulators of G1-phase progression. Genes Dev 1999;13:1501-1512.

8 Nevins JR: E2F: a link between the Rb tumor suppressor protein and viral oncoproteins. Science 1992;258:424-429.

9 Ohtani N, Yamakoshi K, Takahashi A, Hara E: The p16INK4a-RB pathway: molecular link between cellular senescence and tumor suppression. J Med Invest 2004;51:146-153.

10 Dickson MA: Molecular pathways: CDK4 inhibitors for cancer therapy. Clin Cancer Res 2014;20:3379-3383.

11 Cicenas J, Kalyan K, Sorokinas A, Jatulyte A, Valiunas D, Kaupinis A, Valius M: Highlights of the latest advances in research on CDK inhibitors. Cancers 2014;6:2224-2242.

12 Evers BM, Townsend CM Jr, Upp JR, Allen E, Hurlbut SC, Kim SW, Rajaraman S, Singh P, Reubi JC, Thompson JC: Establishment and characterization of a human carcinoid in nude mice and effect of various agents on tumor growth. Gastroenterology 1991;101:303311.

13 Babu V, Paul N, Yu R: Animal models and cell lines of pancreatic neuroendocrine tumors. Pancreas 2013;42:912-923.

14 Cakir M, Grossman A: The molecular pathogenesis and management of bronchial carcinoids. Expert Opin Ther Targets 2011;15: 457-491.

15 Kolby L, Bernhardt P, Ahlman H, Wangberg B, Johanson V, Wigander A, Forssell-Aronsson E, Karlsson S, Ahren B, Stenman G, Nilsson O: A transplantable human carcinoid as model for somatostatin receptor-mediated and amine transporter-mediated radionuclide uptake. Am J Pathol 2001;158:745-755.

16 Zitzmann K, De Toni EN, Brand S, Goke B, Meinecke J, Spottl G, Meyer HH, Auernhammer CJ: The novel mTOR inhibitor RAD001 (everolimus) induces antiproliferative effects in human pancreatic neuroendocrine tumor cells. Neuroendocrinology 2007;85:54-60.

17 Spampatti M, Vlotides G, Spottl G, Maurer J, Goke B, Auernhammer CJ: Aspirin inhibits cell viability and mTOR downstream signaling in gastroenteropancreatic and bronchopulmonary neuroendocrine tumor cells. World J Gastroenterol 2014;20:1003810049.
18 Reuther C, Heinzle V, Nölting S, Herterich S, Hahner S, Halilovic E, Jeay S, Wuerthner JU, Aristizabal Prada ET, Spöttl G, Maurer J, Auernhammer CJ: The HDM2 (MDM2) inhibitor NVP-CGM097 inhibits tumor cell proliferation and shows additive effects with 5 -fluorouracil on the p53-p21-Rb-E2F1 cascade in the p53wildtype neuroendocrine tumor cell line GOT1. Neuroendocrinology, Epub ahead of print.

19 Riccardi C, Nicoletti I: Analysis of apoptosis by propidium iodide staining and flow cytometry. Nat Protoc 2006;1:1458-1461.

20 Finn RS, Dering J, Conklin D, Kalous O, Cohen DJ, Desai AJ, Ginther C, Atefi M, Chen I, Fowst C, Los G, Slamon DJ: PD 0332991, a selective cyclin D kinase 4/6 inhibitor, preferentially inhibits proliferation of luminal estrogen receptor-positive human breast cancer cell lines in vitro. Breast Cancer Res 2009; 11:R77.

21 Chung DC: Cyclin D1 in human neuroendocrine: tumorigenesis. Ann NY Acad Sci 2004; 1014:209-217.

22 Tang LH, Contractor T, Clausen R, Klimstra DS, Du YC, Allen PJ, Brennan MF, Levine AJ, Harris CR: Attenuation of the retinoblastoma pathway in pancreatic neuroendocrine tumors due to increased cdk4/cdk6. Clin Cancer Res 2012;18:4612-4620.

23 Shapiro GI: Cyclin-dependent kinase pathways as targets for cancer treatment. J Clin Oncol 2006;24:1770-1783.

24 Beasley MB, Lantuejoul S, Abbondanzo S, Chu WS, Hasleton PS, Travis WD, Brambilla $\mathrm{E}$ : The P16/cyclin D1/Rb pathway in neuroendocrine tumors of the lung. Hum Pathol 2003;34:136-142.

25 Banck MS, Kanwar R, Kulkarni AA, Boora GK, Metge F, Kipp BR, Zhang L, Thorland EC, Minn KT, Tentu R, Eckloff BW, Wieben ED, Wu Y, Cunningham JM, Nagorney DM, Gilbert JA, Ames MM, Beutler AS: The genomic landscape of small intestine neuroendocrine tumors. J Clin Invest 2013;123:25022508.

26 Francis JM, Kiezun A, Ramos AH, Serra S, Pedamallu CS, Qian ZR, Banck MS, Kanwar R, Kulkarni AA, Karpathakis A, Manzo V, Contractor T, Philips J, Nickerson E, Pho N, Hooshmand SM, Brais LK, Lawrence MS, Pugh T, McKenna A, Sivachenko A, Cibulskis K, Carter SL, Ojesina AI, Freeman S, Jones RT, Voet D, Saksena G, Auclair D, Onofrio R, Shefler E, Sougnez C, Grimsby J, Green L, Lennon N, Meyer T, Caplin M, Chung DC, Beutler AS, Ogino S, Thirlwell C, Shivdasani R, Asa SL, Harris CR, Getz G, Kulke M, Meyerson M: Somatic mutation of CDKN1B in small intestine neuroendocrine tumors. Nat Genet 2013;45:1483-1486.

27 Hamilton E, Infante JR: Targeting CDK4/6 in patients with cancer. Cancer Treat Rev 2016; 45:129-138.
28 Konecny GE, Winterhoff B, Kolarova T, Qi J, Manivong K, Dering J, Yang G, Chalukya M, Wang HJ, Anderson L, Kalli KR, Finn RS, Ginther C, Jones S, Velculescu VE, Riehle D, Cliby WA, Randolph S, Koehler M, Hartmann LC, Slamon DJ: Expression of p16 and retinoblastoma determines response to CDK4/6 inhibition in ovarian cancer. Clin Cancer Res 2011;17:1591-1602.

29 Boora GK, Kanwar R, Kulkarni AA, Pleticha J, Ames M, Schroth G, Beutler AS, Banck MS: Exome-level comparison of primary well-differentiated neuroendocrine tumors and their cell lines. Cancer Genet 2015;208:374-381.

30 Vandamme T, Peeters M, Dogan F, Pauwels P, Van Assche E, Beyens M, Mortier G, Vandeweyer G, de Herder W, Van Camp G, Hofland LJ, Op de Beeck K: Whole-exome characterization of pancreatic neuroendocrine tumor cell lines BON-1 and QGP-1. J Mol Endocrinol 2015;54:137-147.

31 Sheppard KE, McArthur GA: The cell-cycle regulator CDK4: an emerging therapeutic target in melanoma. Clin Cancer Res 2013;19: 5320-5328.

32 Gillam MP, Nimbalkar D, Sun L, Christov K, Ray D, Kaldis P, Liu X, Kiyokawa H: MEN1 tumorigenesis in the pituitary and pancreatic islet requires Cdk4 but not Cdk2. Oncogene 2015;34:932-938.

33 Wu A, Wu B, Guo J, Luo W, Wu D, Yang H, Zhen Y, Yu X, Wang H, Zhou Y, Liu Z, Fang $\mathrm{W}$, Yang Z: Elevated expression of CDK4 in lung cancer. J Transl Med 2011;9:38.

34 Herrera-Abreu MT, Palafox M, Asghar U, Rivas MA, Cutts RJ, Garcia-Murillas I, Pearson A, Guzman M, Rodriguez O, Grueso J, Bellet M, Cortes J, Elliott R, Pancholi S, Baselga J, Dowsett M, Martin LA, Turner NC, Serra V: Early adaptation and acquired resistance to CDK4/6 inhibition in estrogen receptor-positive breast cancer. Cancer Res 2016;76:23012313.

35 Goel S, Wang Q, Watt AC, Tolaney SM, Dillon DA, Li W, Ramm S, Palmer AC, Yuzugullu H, Varadan V, Tuck D, Harris LN, Wong KK, Liu XS, Sicinski P, Winer EP, Krop IE, Zhao JJ: Overcoming therapeutic resistance in HER2positive breast cancers with CDK4/6 inhibitors. Cancer Cell 2016;29:255-269.

36 Wyatt MD, Wilson DM 3rd: Participation of DNA repair in the response to 5-fluorouracil. Cell Mol Life Sci 2009;66:788-799.

37 Hentic O, Hammel P, Couvelard A, Rebours V, Zappa M, Palazzo M, Maire F, Goujon G, Gillet A, Levy P, Ruszniewski P: FOLFIRI regimen: an effective second-line chemotherapy after failure of etoposide-platinum combination in patients with neuroendocrine carcinomas grade 3. Endocrine-Related Cancer 2012; 19:751-757.

38 Heetfeld M, Chougnet CN, Olsen IH, Rinke A, Borbath I, Crespo G, Barriuso J, Pavel M, O'Toole D, Walter T: Characteristics and treatment of patients with G3 gastroenteropancreatic neuroendocrine neoplasms. Endocr Relat Cancer 2015;22:657-664. 
39 Hadoux J, Malka D, Planchard D, Scoazec JY, Caramella C, Guigay J, Boige V, Leboulleux S, Burtin P, Berdelou A, Loriot Y, Duvillard P, Chougnet CN, Deandreis D, Schlumberger M, Borget I, Ducreux M, Baudin E: Post-firstline FOLFOX chemotherapy for grade 3 neuroendocrine carcinoma. Endocr Relat Cancer 2015;22:289-298.

40 Zitzmann K, de Toni E, von Ruden J, Brand S, Goke B, Laubender RP, Auernhammer CJ: The novel Raf inhibitor Raf265 decreases Bcl2 levels and confers TRAIL-sensitivity to neuroendocrine tumour cells. Endocr Relat Cancer 2011;18:277-285.

41 Iida S, Miki Y, Ono K, Akahira J, Nakamura Y, Suzuki T, Sasano H: Synergistic anti-tumor effects of RAD001 with MEK inhibitors in neuroendocrine tumors: a potential mechanism of therapeutic limitation of mTOR inhibitor. Mol Cell Endocrinol 2012;350:99106.

42 Valentino JD, Li J, Zaytseva YY, Mustain WC, Elliott VA, Kim JT, Harris JW, Campbell K, Weiss H, Wang C, Song J, Anthony L, Townsend CM Jr, Evers BM: Cotargeting the PI3K and RAS pathways for the treatment of neuroendocrine tumors. Clin Cancer Res 2014;20:1212-1222.

43 Kunnimalaiyaan M, Ndiaye M, Chen H: Neuroendocrine tumor cell growth inhibition by ZM336372 through alterations in multiple signaling pathways. Surgery 2007;142:959964; discussion 959-964.

44 Van Gompel JJ, Kunnimalaiyaan M, Holen K, Chen H: ZM336372, a Raf-1 activator, suppresses growth and neuroendocrine hormone levels in carcinoid tumor cells. Mol Cancer Ther 2005;4:910-917.

45 Cook MR, Pinchot SN, Jaskula-Sztul R, Luo J, Kunnimalaiyaan M, Chen H: Identification of a novel Raf-1 pathway activator that inhibits gastrointestinal carcinoid cell growth. Mol Cancer Ther 2010;9:429-437.

46 Briest F, Grabowski P: PI3K-AKT-mTORsignaling and beyond: the complex network in gastroenteropancreatic neuroendocrine neoplasms. Theranostics 2014;4:336-365.

47 Collins I, Garrett MD: Targeting the cell division cycle in cancer: $\mathrm{CDK}$ and cell cycle checkpoint kinase inhibitors. Curr Opin Pharmacol 2005;5:366-373.

48 Dean JL, McClendon AK, Knudsen ES: Modification of the DNA damage response by therapeutic CDK4/6 inhibition. J Biol Chem 2012;287:29075-29087.

49 Fujinaka Y, Matsuoka K, Iimori M, Tuul M, Sakasai R, Yoshinaga K, Saeki H, Morita M, Kakeji Y, Gillespie DA, Yamamoto K, Takata M, Kitao H, Maehara Y: ATR-Chk1 signaling pathway and homologous recombinational repair protect cells from 5-fluorouracil cytotoxicity. DNA Repair 2012;11:247-258.

50 Dai Y, Grant S: New insights into checkpoint kinase 1 in the DNA damage response signaling network. Clin Cancer Res 2010;16:376383.
51 McClendon AK, Dean JL, Rivadeneira DB, Yu JE, Reed CA, Gao E, Farber JL, Force T, Koch WJ, Knudsen ES: CDK4/6 inhibition antagonizes the cytotoxic response to anthracycline therapy. Cell Cycle 2012;11:2747-2755.

52 Roberts PJ, Bisi JE, Strum JC, Combest AJ, Darr DB, Usary JE, Zamboni WC, Wong KK, Perou CM, Sharpless NE: Multiple roles of cyclin-dependent kinase 4/6 inhibitors in cancer therapy. J Natl Cancer Inst 2012;104: 476-487.

53 Yao JC, Shah MH, Ito T, Bohas CL, Wolin EM, Van Cutsem E, Hobday TJ, Okusaka T, Capdevila J, de Vries EG, Tomassetti P, Pavel ME, Hoosen S, Haas T, Lincy J, Lebwohl D, Oberg K: Everolimus for advanced pancreatic neuroendocrine tumors. N Engl J Med 2011; 364:514-523.

54 Kulke MH, Shah MH, Benson AB 3rd, Bergsland E, Berlin JD, Blaszkowsky LS, Emerson L, Engstrom PF, Fanta P, Giordano T, Goldner WS, Halfdanarson TR, Heslin MJ, Kandeel F, Kunz PL, Kuvshinoff BW 2nd, Lieu C, Moley JF, Munene G, Pillarisetty VG, Saltz L, Sosa JA, Strosberg JR, Vauthey JN, Wolfgang C, Yao JC, Burns J, Freedman-Cass D: Neuroendocrine tumors, version 1. 2015. J Natl Compr Cancer Netw 2015;13:78-108.

55 Kunz PL, Reidy-Lagunes D, Anthony LB, Bertino EM, Brendtro K, Chan JA, Chen H, Jensen RT, Kim MK, Klimstra DS, Kulke MH, Liu EH, Metz DC, Phan AT, Sippel RS, Strosberg JR, Yao JC: Consensus guidelines for the management and treatment of neuroendocrine tumors. Pancreas 2013;42:557-577.

56 Pavel M, Baudin E, Couvelard A, Krenning E, Oberg K, Steinmuller T, Anlauf M, Wiedenmann B, Salazar R: ENETS Consensus Guidelines for the management of patients with liver and other distant metastases from neuroendocrine neoplasms of foregut, midgut, hindgut, and unknown primary. Neuroendocrinology 2012;95:157-176.

57 Oberg K, Knigge U, Kwekkeboom D, Perren A: Neuroendocrine gastro-entero-pancreatic tumors: ESMO Clinical Practice Guidelines for diagnosis, treatment and follow-up. Ann Oncol 2012;23(suppl 7):vii124-vii130.

58 Wagle N, Grabiner BC, Van Allen EM, AminMansour A, Taylor-Weiner A, Rosenberg M, Gray N, Barletta JA, Guo Y, Swanson SJ, Ruan DT, Hanna GJ, Haddad RI, Getz G, Kwiatkowski DJ, Carter SL, Sabatini DM, Janne PA, Garraway LA, Lorch JH: Response and acquired resistance to everolimus in anaplastic thyroid cancer. N Engl J Med 2014;371:14261433.

59 He K, Chen D, Ruan H, Li X, Tong J, Xu X, Zhang L, Yu J: BRAFV600E-dependent Mcl-1 stabilization leads to everolimus resistance in colon cancer cells. Oncotarget 2016;7:4769947710 .
60 Vandamme T, Beyens $\mathrm{M}$, de Beeck KO, Dogan F, van Koetsveld PM, Pauwels P, Mortier G, Vangestel C, de Herder W, Van Camp G, Peeters M, Hofland LJ: Long-term acquired everolimus resistance in pancreatic neuroendocrine tumours can be overcome with novel PI3K-AKT-mTOR inhibitors. Br J Cancer 2016;114:650-658.

61 Capozzi M, Caterina I, De Divitiis C, von Arx C, Maiolino P, Tatangelo F, Cavalcanti E, Di Girolamo E, Iaffaioli RV, Scala S, Tafuto S: Everolimus and pancreatic neuroendocrine tumors (PNETs): activity, resistance and how to overcome it. Int J Surg 2015;21(suppl 1): S89-S94.

62 Zitzmann K, Ruden J, Brand S, Goke B, Lichtl J, Spottl G, Auernhammer CJ: Compensatory activation of Akt in response to mTOR and Raf inhibitors - a rationale for dual-targeted therapy approaches in neuroendocrine tumor disease. Cancer Lett 2010; 295:100-109.

63 Vora SR, Juric D, Kim N, Mino-Kenudson M, Huynh T, Costa C, Lockerman EL, Pollack SF, Liu M, Li X, Lehar J, Wiesmann M, Wartmann M, Chen Y, Cao ZA, Pinzon-Ortiz M, Kim S, Schlegel R, Huang A, Engelman JA: CDK 4/6 inhibitors sensitize PIK3CA mutant breast cancer to PI3K inhibitors. Cancer Cell 2014;26:136-149.

64 Lange CA, Yee D: Killing the second messenger: targeting loss of cell cycle control in endocrine-resistant breast cancer. Endocr Relat Cancer 2011;18:C19-C24.

65 Castedo M, Ferri KF, Kroemer G: Mammalian target of rapamycin (mTOR): pro- and anti-apoptotic. Cell Death Differ 2002;9:99-100.

66 Porta C, Paglino C, Mosca A: Targeting PI3K/ Akt/mTOR signaling in cancer. Front Oncol 2014;4:64.

67 Xiong Y, Zhang H, Beach D: D type cyclins associate with multiple protein kinases and the DNA replication and repair factor PCNA. Cell 1992;71:505-514.

68 Koundrioukoff S, Jonsson ZO, Hasan S, de Jong RN, van der Vliet PC, Hottiger MO, Hubscher U: A direct interaction between proliferating cell nuclear antigen (PCNA) and Cdk2 targets PCNA-interacting proteins for phosphorylation. J Biol Chem 2000;275: 22882-22887.

69 Punchihewa C, Inoue A, Hishiki A, Fujikawa Y, Connelly M, Evison B, Shao Y, Heath R, Kuraoka I, Rodrigues $\mathrm{P}$, Hashimoto H, Kawanishi M, Sato M, Yagi T, Fujii N: Identification of small molecule proliferating cell nuclear antigen (PCNA) inhibitor that disrupts interactions with PIP-box proteins and inhibits DNA replication. J Biol Chem 2012;287: 14289-14300.

70 Rousseau D, Cannella D, Boulaire J, Fitzgerald P, Fotedar A, Fotedar R: Growth inhibition by CDK-cyclin and PCNA binding domains of p21 occurs by distinct mechanisms and is regulated by ubiquitin-proteasome pathway. Oncogene 1999;18:4313-4325. 